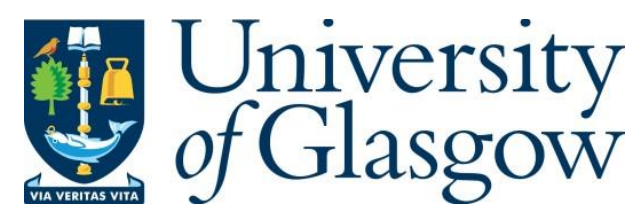

Salgado, E. G. and Dekkers, R. (2018) Lean product development: nothing new under the sun? International Journal of Management Reviews, 20(4), pp. 903-933.

There may be differences between this version and the published version. You are advised to consult the publisher's version if you wish to cite from it.

This is the peer reviewed version of the following article,

Salgado, E.G. and Dekkers, R. (2018) Lean product development: nothing new under the sun? International Journal of Management Reviews, 20(4), pp. 903-933, which has been published in final form at http://dx.doi.org/10.1111/ijmr.12169

This article may be used for non-commercial purposes in accordance with Wiley Terms and Conditions for Self-Archiving.

http://eprints.gla.ac.uk/149711/

Deposited on: 12 October 2017

Enlighten - Research publications by members of the University of Glasgow http://eprints.gla.ac.uk 


\section{Lean Product Development: Nothing New Under the Sun?}

\section{Eduardo Gomes Salgado ${ }^{1}$ and Rob Dekkers ${ }^{2}$}

${ }^{1}$ Corresponding author. Exact Science Institute, Federal University of Alfenas, Alfenas, Minas Gerais State, Brazil e-mail: eduardosalgado@unifal-mg.edu.br, ph.: + 55 (35) 32991336

2 Adam Smith Business School, University of Glasgow, Glasgow G12 8QQ, United Kingdom e-mail: rob.dekkers@glasgow.ac.uk,ph.: + 44 (0)141 3304670

\section{Funding}

This work was supported by the FAPEMIG Foundation (APQ-00976-13) and the CNPq (Process 249160/2013-7). We also would like to thank the anonymous reviewers for comments on an earlier version of this manuscript. 


\title{
Lean Product Development: Nothing New Under the Sun?
}

\begin{abstract}
The concept of lean product development has attracted the attention of many scholars since its inception in the 1990s derived from practices at Toyota Motor Company. Key to this approach to new product development are a few methods derived from lean production as well as longer established practices, such as concurrent engineering. This makes one wonder whether lean product development is a new practice, a new method or an encapsulation of already existing methods at the time; this quest about the roots and tenets of lean product development, also in comparison to other methods for new product development, is the onus of this paper. This journey takes this propositional paper not only to the roots of lean product development and the context of its era of conception, but also to what this concept adds to other extant methods for new product development. Particularly, this comparison draws out that other methods are trying to achieve the same objectives: the creation of products and services with value to the customer, the reduction of time-to-market and the efficient use of resources. This inference implies that managers of new product (and service) development can choose from a wider pallet of methods and approaches to enhance the performance of R\&D and to connect better to manufacturing (including supply chains). Inevitably, this has implications for research on (lean) product and service development; hence, this paper sets out a research agenda based on the deliberations and gaps that have been uncovered in the discourse.
\end{abstract}

Keywords: concurrent engineering; lean product development; lean production; new product development; quality function deployment; value stream mapping 


\section{Lean Product Development: Nothing New Under the Sun?}

\section{Introduction}

Traditionally lean thinking, as an approach to rationalisation, is associated with manufacturing; after its conception for manufacturing (Ohno, 1988; Womack et al., 1991) there is an increasing number of attempts to transfer its principles, tools and techniques to other processes, such as new product development (NPD) (e.g. Baines et al., 2006, p. 1539; Hoppmann et al., 2011, p. 3; Salgado et al., 2014, p. 3). This attempt at applying it to NPD is often designated lean product development. The emergence of lean product development should be set off against other approaches for the processes, methods and management of NPD that appear in literature. In this context, some works expose the existence of a wide array of approaches: sequential phasing for NPD (e.g. Bullinger et al., 2003, p. 281; Krishan et al., 1997; Takeuchi and Nonaka, 1986); product platforms (for example Meyer and Utterback, 1993; Sanchez, 2004; Shamsuzzaho and Kekale, 2010); concurrent engineering (for instance Koufteros et al., 2001); waterfall models (e.g. Bassler et al., 2014, pp. 308-309; Bullinger et al., 2003, p. 281; Joore and Brezet, 2014, p. 93); stage-gate models (for example Cooper, 1990); spiral development (e.g. Bassler et al., 2014, pp. 308-309; Joore and Brezet, 2014, p. 93); capability maturity model (for instance Dooley et al., 2001; Veldman and Klingenberg, 2009); design for six sigma (for example Bañuelas and Antony, 2003); and product life-cycle management (e.g. Hicks and McGovern, 2009). Hence, lean product development can only be seen as one of the approaches currently being adopted by organisations that are attempting to maximise value, increase quality, shorten lead times, increase efficiency of resources and lower costs for NPD. This raises the first question of this review: how is lean product development based on lean thinking positioned in the rationalisation of NPD? 


\section{Objectives for Review}

In this context of lean product development being one approach to rationalisation, there are three concerns. First, although various studies on NPD have been conducted (Baines et al., 2006, p. 1542), it appears that the mere conversion of principles taken from lean manufacturing to NPD settings does not necessarily equate to an effective, lean NPD; it is sufficient to mention that numerous companies face difficulties in carrying out lean product development appropriately (León and Farris, 2011, p. 29). Second, for some researchers (for instance, Freire and Alarcón, 2002, p. 252; Pernstål et al., 2013, p. 2799) lean product development is not easy or not simply a matter of implementing some of its techniques and methods; they claim that lean is a way of thinking that should be adopted throughout the whole company. Third, MacCormack et al. (2012, p. 34) mention that companies must make substantial efforts to ensure that their NPD approaches are better aligned with their business needs. Thus, it seems clear that NPD needs to be fully integrated with strategic management, which consequently should apply to lean product development, too. This strategic alignment makes it a more difficult task to discern the benefits of lean product development as a singular approach. Therefore, the second objective of this review is to shed some light on this controversy over what the principles and scope of lean product development are versus which benefits it brings to firms.

In addition to addressing this controversy about the uniqueness of its principles what it covers and what it brings to a firm, another reason for this paper is that lean product development is still considered a relatively new and promising approach to NPD, and therefore still lacks systematic comparison with other approaches to NPD (Rozenfeld et al., 2006, p. 34; Schulze and Störmer, 2012, p. 71). Furthermore, Hoppmann et al. (2011, p. 13) assert that there are no empirical studies about the implementation of lean product development, apart from those about Toyota's decades-long evolution of NPD. This stance is supported by Johansson and 
Sundin (2014, p. 119), who found that the literature has offered fairly poor evidence regarding the industrial applicability of lean product development. In addition, Letens et al. (2011, p. 69) contend that there is much more understanding of the characteristics of effective lean manufacturing systems than those of effective lean product development. Therefore, a number of questions remain concerning the applicability of lean thinking concepts in NPD to various organisations and contexts. The lack of evidence underlines that it is necessary to conduct a study comparing lean thinking for NPD with lean thinking for manufacturing. Once this comparison has been made, it will be possible to answer the question as to what lean product development brings to the table that other approaches do not. Therefore, this review scrutinises the tenets of lean thinking for NPD and contributes to the debate on its added value relative to other approaches, concepts and methods.

\section{Scope and Outline of Paper}

Thus, this review evaluates the conceptualisation of lean product development, identifies the benefits it brings to organisations and compares it to other approaches for NPD. The five principles of lean thinking outlined by Womack and Jones (1996, pp. 16-26) are taken as a starting point, knowing that others have used and extended this view for lean product development. Making use of this particular conceptualisation for lean product development, the review questions for this paper are: (1) beyond lean thinking which characteristics, methods and tools have been added for the conceptualisation of lean product development?, (2) do authors refer to methods and tools other than those covered by this original writing about lean thinking and the original concepts for lean product development?, and (3) is there mention of or comparison to other methodologies for NPD? By addressing these three questions this manuscript adds not only a critical review of lean product development, but also offers a holistic perspective to existing reviews of lean product development. 
The paper is organised as follows. The review starts by looking at its rationale and approach in the next section; the results of the systematic retrieval of literature are also found there. A section about the tenets of lean product development follows; this section also discusses the some of the assumptions made by authors about applying lean thinking to NPD. The section thereafter discusses the findings, while a final section concludes with implications for research and practice.

\section{Methodology for Review}

The approach to the literature review consists of two stages. The first stage is a systematic literature review, following the guidelines of Cronin et al. (2008) and Tranfield at al. (2003); the purpose of this review is to find what studies about lean product development have covered in terms of lean thinking. The second purpose of this systematic review is to find what conceptualisations of lean product development have been developed in literature beyond lean thinking. This search also covers what evidence is found by authors justifying the focus on lean product development as a solution to increasing NPD productivity. The results of the systematic review give way to a narrative overview (Green et al., 2006, pp. 103-104). This narrative discussion of the papers, as the second stage, is necessary because lean product development is often presented as an integral solution for NPD or as covering many aspects of NPD. Furthermore, attention for lean product development does not rely on evidence but on conceptualisation. Thus, the second stage, the narrative discussion of sources on lean product development allows a wider range of sources to be drawn on than those found during the first stage.

\section{Retrieval of Publications}

To find publications relevant to the first stage, the systematic literature review, three databases have been used: EBSCOHost, Google Scholar and Scopus; this is commensurate 
with recommendations to use at least two databases (Green et al., 2006, p. 107). Subsequently, the search relied on appropriate keywords derived from those most used by previous publications about lean product development: 'lean design engineering', 'lean engineering', 'lean product development' and 'lean product and process development'. We have retrieved a wide range of publications, including academic articles published in journals and accessible proceedings of conferences up to 2015. Because peer-reviewed journal publications are not necessarily the only reliable source for analysis (see for example, Conn et al. [2003] and Hopewell et al. [2007] about so-called grey literature, and MacDonald and Kam [2007] on how publishing is a game) and because the origin of lean thinking applied to NPD needs to be traced, a wider range of publications has been considered for inclusion: monographs, chapters in edited books, doctoral theses, presentations, professional publications, reports and working papers. Next, studies were selected based on their relevance to research about lean product development and NPD; both empirical and propositional studies were taken into account. Furthermore, snowballing (see Greenhalgh and Peacock [2005] and Wohlin and Prikladnicki [2013]) was applied to the publications found through the databases. This search strategy using three databases and snowballing for the first step of the literature review yielded the foundation for the analysis.

To determine whether retrieved publications would contribute to analysis, exclusion criteria were applied. First, only studies that were focusing on lean product development were used; sources about other applications, such as construction (e.g. Freire and Alarcón, 2002), information technology (for example Pernstål et al., 2013) and service (for instance Joore and Brezet, 2015) were excluded. Also, studies that looked at teaching lean product development (for example, Rossi, Kerga et al., 2012) or student projects (e.g. Graebsch et al., 2007) were 
discarded. Second, master's dissertations ${ }^{1}$ were omitted since these may vary in quality. A case in point is the dissertation by Bauch (2004) describing three new types of waste applied to lean product development; even though referred to by many (e.g. Darwish et al., 2010; Oehmen and Rebentisch, 2010b; Pessôa et al., 2007; Wang, Ming et al., 2011), it did not make it into the list. Third, books that were not monographs were left out during the retrieval processes, because they did not rely explicity on extant knowledge; for example, Mynott's (2012) managerial guide was discarded, even though used in other academic works, such as Rauch et al. (2015, p. 112). Fourth, publications in conference proceedings that appeared later in more or less similar form in an academic journal were omitted. Cases in point are the conference proceedings by Browning (2000), which was published in an academic journal (Browning 2003), and by Gudem et al. (2011), later reported as Gudem et al. (2013). The application of these four exclusion criteria led to 207 publications to be considered; see Table 1 and the Appendix for those retrieved publications that are not cited in the text of this paper or its tables.

\section{[Insert Table 1 about here]}

[Insert Figure 1 about here]

\section{Descriptive Results of Systematic Literature Review}

Due to our search strategy a wide range of publications was found (see Figure 1). The dominating types of publications that we retrieved are contributions to conferences and papers in academic journals. For those who are interested in search strategies for literature reviews it should be noted that most of the other types of sources were obtained through Google Scholar, snowballing and to a lesser extent Scopus; EBSCOHost yielded only one 
contribution to a conference and one professional publication in addition to the 14 papers in academic journals. The four presentations and the report in our sample were found through Google Scholar and snowballing. In addition to EBSCOHost yielding fewer varieties in types of publications, all its sources except one (Sorli et al., 2011) were also retrieved through the other two search engines. Looking at the types of sources across the years (see Figure 2), it appears that according to our retrieval process initially journal publications paved the way and that from 2005 onwards there was a substantial increase in other types of publication. The large majority of sources are found as contributions to conference proceedings $(45 \%)$ and as academic papers (39\%). However, other types of sources, such as presentations and working papers, yielded additional insight into the conceptualisation of lean product development, as will be emerging in the section 'Is Lean Product Development the Only Way?' Furthermore, Figure 2 shows that the attention for lean product development has increased, peaking in 2011. Note that our period of analysis stretches beyond Schulze and Störmer (2012, p. 73), who find an increase in publications only until 2008, but not the flattening out in later years; for the similar period 1996-2008 our retrieved number of papers is lower due to exclusion criteria, for example, excluding master's dissertations. Also the review by Hille and Eseonu (2015, p. 88) shows a decline in publications after 2011. This means that the number of publications, caused by an increase in publications over approximately 20 years though declining at the end of the period considered, in conjunction with the variety of publications provides possibly rich insight into the conceptualisation of lean product development, even though contributions to conference proceedings and publications in academic journals dominate.

\section{[Insert Figure 2 about here] \\ [Insert Figure 3 about here]}


This surge in publications, particularly from 2006 until 2011, may possibly be linked to specific projects and initiatives. To find out which authors and institutes prevail in publications, dominating institutes have been set off against dominating authors; for each the threshold was five publications in our set of retrieved studies. The classification of the institute was attributed to the first author, unless it was clear from other co-authors that another academic institute dominated; if it was a practitioner co-authoring with an academic, then the academic was taken as being indicative for attributing the academic institute. Figure 3 demonstrates the contributions of the five leading institutes over the period 1996-2015, according to our classification; only Chalmers University of Technology and the Norwegian University of Science and Technology remain active after the peak in 2010-2013 in this figure. The analysis further revealed that Cranfield University and the Massachusetts Institute of Technology (MIT) have yielded most publications in this domain. For Cranfield University this is related to the LeanPPD project (EU funded); this project also had academic partners, such as the École Polytechnique Fédérale de Lausanne and Politecnico di Milano, which also appear in the table. For MIT it is the Lean Aerospace Initiative (part industry funded). Related to the Lean Aerospace Initiative, there is also a UK equivalent: the UK Lean Aerospace Initiative; however, that seems to have yielded less output (for example, the publications of the University of Bath). Both the LeanPPD project and the UK Lean Aerospace Initiative, the latter as a grand challenge, are related to the Innovative Manufacturing Centres (see Dekkers, 2010) and their output could also be considered from the relative performance of these research centres. Given that not only these institutes but also others have contributed multiple studies to the set of retrieved papers, we have not considered 'marginality' (see Karabag and Berggren, 2016, p. 15), although we discarded contributions to conferences that were later published in academic journals. The foci of these institutes and their projects are also reflected in the industries covered (see Figure 4). 
Compensating for publications that did not specify any industry, such as some of the propositional writings ${ }^{2}$, the aerospace industry appeared in $25 \%$ of the publications and the automotive industry in $30 \%$. Although other industries have been investigated, it may well be that these two most frequent industries have particular challenges. The only publication that confirms this stance is the project by Ringen and Welo (2015), also published as Welo and Ringen (2015); they state that systems engineering companies (aerospace and defence) tend to be more immature compared to other sectors when considering lean practices and capabilities for knowledge (Ringen and Welo, 2015, p. 358). Moreover, lean practices are originating in the automotive industry, which may explain its leverage in the adaptive radiation of lean product development. Perhaps the wide range of sources, the specific search strategy, the peak of publications induced by specific projects at specific institutes and the decision not to compensate for marginality may partly explain the increase in publications and the flattening out of the sources after 2011.

\section{[Insert Figure 4 about here]}

\section{Analysis of Papers}

The retrieved publications were then classified and analysed. In addition to the type of publication and the originating institute, the categorisation noted the research method, the industrial sector or sectors investigated, coverage of the NPD processes and the perspective of scientific disciplines (business and management, engineering, innovation and technology management). Note that a paper was classified as propositional when an example was only used for illustration rather than analysis; Welo (2011) is a case in point. Furthermore, the papers were analysed on how they addressed the review questions; for all sources both 
authors had to agree on the analysis and notes taken, which were recorded on a spreadsheet. The data from the categorisation and the analysis formed the base for the narrative review that follows.

During the analysis, not only did we search for papers about lean product development for the perspective of its conceptualisation as described so far, we also explicitly looked for origins of concepts as a second step of the literature review. When papers were analysed about lean product development, the three databases and search engines were used to look for origins of concepts beyond the period that lean product development was named in literature. Cases in point are the works of Abernathy and Rosenbloom (1969) and Pugh (1981). This search ensured that additional relevant papers were found, akin to Greenhalgh and Peacock's (2005, p. 1065) recommendation for using 'informal approaches', as they call them. Hence, the second step enhanced our search strategy by its wider coverage and broader range of concepts.

\section{Examining the Basic Tenets of Lean Product Development}

Crucial to understanding the contribution of lean product development as an approach to the processes and management of NPD is to know what it is about. For this purpose, this section explores the relevant features of lean thinking for NPD before moving on to discussing its principles, tools and methods. The final subsection pays attention to performance measures that have been associated with lean product development.

However, before going into detail about the application of principles of lean thinking to NPD, such reasoning should be based on a comparison of manufacturing and NPD. To this purpose, only 15 publications discuss the comparison beyond mentioning that production is based on material flows and that product development concerns the flow of information. In this respect, two of the 15 papers, Gudem and Welo (2010, p. 313) and Gudem et al. (2013, p. 
73), mention product development is a more complex process since it concerns the generation and use of information. According to them, waste in product development is to be understood as the wrong input rather than undertaking unnecessary activities, for example, Salgado et al. (2014, p. 6) look at different types of waste. In this spirit, some other of these 15 papers (e.g. Reinertsen, 2005, pp. 41-42; Reinertsen and Shaeffer, 2005, pp. 51-52) take the variability as a starting point; but Welo et al. (2012, p. 5) note that for 'new product development, variability is a means to generate knowledge that reduces the risk of taking new products to the market, and a means to generate those very few exceptional opportunities' (albeit based on another source). Nevertheless, others (e.g. Welo, 2011, pp. 318-319) compare manufacturing and product development on its characteristics but without considering its impact. However, it is noteworthy that Khan et al. (2013, p. 1115) posit that lean product development is not just lean manufacturing applied to product development; this stance can also be found in Bjarnoe (2006, p. 45). Aligned with this perspective, McManus et al. (2007, p. 110) compare product development with mixed-model production. Their stance is closer to Hinckeldeyn et al. (2015, p. 470) who consider product development similar to job shops. These considerations may imply that the degree of novelty plays a role for managing product development (ibid., p. 470), which extends to lean product development. However, none of the studies refers to the degree of novelty, except Raudberget (2010, p. 692) for unproven and new technology in the context of set-based concurrent engineering. This implies that the conceptualisation of lean product development and the application of lean thinking to NPD is based on an incomplete discussion as to what extent they are applicable and how production and product development differ in relevant characteristics.

\section{Application of Lean Thinking to Product Development}

Setting aside for the moment the incomplete foundation for applying principles of lean thinking to NPD, its philosophy appears in the original writing by Womack and Jones (1996, 
pp. 16-26); they state that lean thinking has five principles: value, value stream (mapping), flow, pull production and perfection (note waste is a consequence of creating value streams, and flow and pull production are interrelated). The thought is that these five principles do apply to lean product development, too, in some way. Whereas according to León and Farris (2011, p. 43), there is agreement that lean thinking must be translated to fit the specific context of NPD, implementing only a few of its principles is not enough for achieving lean product development, according to Pernstål et al. (2013, p. 2799). Based on lean thinking, this makes sense because the implementation of a few principles will not result in the elimination of all waste within the context of NPD. Therefore, León and Farris (2011, p. 43) claim that the critical principles that best describe the application of lean thinking to NPD have not yet been reached. Some have expanded the number of principles; a case in point is the paper by Liker and Morgan (2006, pp. 10-15), who present 13 principles that underpin lean product development. It should be noted that these principles do not really differ from those highlighted by Womack and Jones (1996, pp. 16-26), but should be seen as a more detailed explanation. In addition, Oppenheim et al. (2011) enumerate so-called enablers for systems engineering that are related to lean product development. However, many of these lean practices are not new (Siyam et al., 2015, p. 198) and can be understood as best practices for NPD. Note that for the purpose of this review we have reformulated the lean principles for NPD as: value, value stream (mapping), waste, flow/pull production and perfection; the foci of retrieved papers made this classification a more appropriate interpretation for the further discussion. Thus, these more recent writings do not shed light on the fundamental principles of lean product development.

\section{[Insert Table 2 about here]}

Therefore, let us examine the reformaluted five principles of lean thinking applied to NPD by first looking at the concept of value; it is also the principle used in most works in the 
retrieved set of publications, see Table 2. However, there are two meanings attributed to the concept of value. The first of these two notions is that value is something found in manufacturing, and therefore focuses on the added value of processes and activities; this interpretation is principally the inverse of waste. In this respect, Vosgien et al. (2011, p. 331) possibly talk about 'process value' as distinct from 'product value'. A case in point is the publication by Gershenson and Pavnaskar (2003); when they refer to value it is to be seen in the context of value stream mapping and waste. As a second interpretation of value, some works, for example, Haque and James-Moore (2004a, p. 12) and von Würtemberg et al. (2011, p. 2), intimate that the philosophy of lean product development has a strong focus on capturing the voice of the customer, and on defining and maximising the perceived value by the customer. However, it is possible to find research in the late 1960s and early 1970s using the voice of the customer to increase the value of the product; for example, there are precedents with quality function deployment (QFD) (Maritan, 2015, pp. 12-13) and a Scandinavian approach called 'participatory design' (Vardouli, 2015, pp. 13-14). Both approaches involve customers in NPD (e.g. Chan and Wu, 2002, p. 464; Ind and Coates, 2013, p. 88). Analysis of value - often claimed as central to creating value - dates back to efforts in improving value in 1947 at General Electric during the Second World War (Shillito and De Marle, 1992, p. 237). Hence, it can be concluded that the principle of creating value for the customer predates the conception of lean product development.

The second principle of lean thinking is the optimisation of the value stream; in Table 2 it is ranked as the third-ranking principle in terms of occurrence in the retrieved set of publications. This principle is mostly associated with value stream mapping. According to Dal Forno et al. (2014, p. 780), this is an important facet of lean thinking and is used for identifying value-adding activities and activities that are considered wasteful for materials and the flow of information and people. Furthermore, the deployment of value stream 
mapping should lead to highlighting potential areas for improvement, while additional tools are used to conduct analysis (Tyagi et al., 2015, p. 205). However, it is difficult to apply value stream mapping to the analysis of NPD processes due to the difficulties in defining what is value, according to León and Farris (2011, p. 43). Moreover, having a closer look at this, the depiction and its methods are merely an adoption of the ASME process-mapping standard, dating back to the 1920s. Again, this was developed for manufacturing rather than for NPD. In that context, it is worth mentioning that NPD processes have an iterative nature; early decisions are later revisited and perhaps changed due to progressive insight about product specifications and technological capabilities (see Chao and Ishii, 2006, p. 492; Pahl et al., 2007, pp. 126, 410-38; Radhakrishan and McAdams, 2005, p. 378). None of the literature on lean product development (and it is extensive) has examined this argument. Akin the concept of value for the customer, the mapping of processes and its analysis are rooted in approaches known before the concept of lean product development came to light; moreover, these principles derived from manufacturing are declared to be valid without argumentation about the iterative character of NPD.

The latter flaw also surfaces for the third principle of lean thinking that is often mentioned in the context of lean product development, which is 'flow'; from our particular perspective flow and pull production are strongly interrelated and appear in our set of retrieved publications as ranking fourth (Table 2). This principle assumes that NPD and manufacturing are sufficiently isomorph from the perspective of control and process improvement. Contrastingly, Hinckeldeyn et al. (2015, p. 470) have reasoned that NPD processes have more in common with job shops than with production lines; this argument seems to be ignored in the literature. Consequently, Haque and James-Moore (2004b, p. 1394) maintain that to facilitate the principles of flow and pull production several tools for obtaining and processing information may be used in organisations. The same authors claim that if 
information is 'pulled' it will be more swiftly available to the entity requiring it, and, thus, it will compress the lead time for NPD, while noting that this is dependent on the degree of novelty. This notion is supported by Hinckeldeyn et al. (2015, p. 460) who contend that the application of production management principles to engineering processes is related to the degree of novelty that is inherent in engineering projects in companies. None of the other literature on lean product development has questioned the validity of and the contingencies for transferring principles from manufacturing to NPD; this should be considered a prominent deficit. This discussion brings to the fore that the principle of flow together with the related fourth principle - pull production - carries little relevance to NPD as it stands, albeit that perhaps the degree of novelty is a determinant.

\section{[Insert Table 3 about here]}

The final principle of lean thinking is the elimination of waste and striving for perfection (taken in our text as two separate but related principles); whereas the elimination of waste appears in second rank (after value), the principle of explicitly striving for perfection is least mentioned in the set of retrieved publications. To apply this principle seven sources of waste in the context of lean production are described by Shingo (1996). For lean product development Bauch (2004, p. 47) has suggested three additional sources of waste: reinvention, lack of discipline and limitations inherent in ICT (see Table 3). More examples of the categorisation of waste during product development processes can be found in Bauch (2004) and Oppenheim (2004). However, it could be questioned whether these classifications are trivial and often unnecessary because of the degree of novelty as determinant. For instance, according to Baines et al. (2006, p. 1544), work-in-progress and excess inventory in NPD is generally in the form of information; however, they note that information is not perceptible. Consequently, the stance is that waste should be minimised or, if possible, eliminated during NPD (von Würtemberg et al., 2011, p. 6). In practice, it will be difficult to 
assign a financial value to information (Baines et al., 2006, p. 1544), except that a distinction between technical information as primary process and information for control processes may be helpful (see concepts of applied systems theory [Dekkers, 2015, p. 83]). Moreover, how does one assess that unnecessary data are stored? Such can only be determined in hindsight rather than by foresight. That becomes even more apparent when considering Stevens and Burley's (1997, p. 16) finding that, on average, 3,000 raw ideas are required to successfully commercialise one new industrial product. This underlines that uncertainties remain until the last moment and that subjectivity is inherent in NPD. Particularly for radical product innovation a new specification for a particular product may not be a task that could simply be eliminated or decreased in lead time. For reducing waste during NPD, one could fall back on striving for perfection (aka the zero-defects approach); Dombrowski and Zahn (2011, p. 1919) and Wang, Ming et al. (2011, p. 13) affirm that it is possible to find errors in all working processes, and in fact this also occurs during product development. The same authors recommend as tools for lean product developments the Kano model, QFD, the target definition matrix and design for assembly to minimise errors. The Kano model was developed during the 1980s by Professor Noriaki Kano and classifies customer preferences into five categories (Shen et al., 2000, p. 92; Yang, 2005, p. 1129). QFD (Chan and Wu, 2002; Cohen, 1988; King, 1987) and design for assembly (Boothroyd, 1987; Sackett and Holbrook, 1988) emerged during the same period. Specifically, design for assembly should be seen as part of the paradigm that design and product engineering should not be disconnected from other functions, which became shortly after known as design for X (e.g. Meerkamm, 1994). Particularly, design for manufacturing and assembly can also be considered similar to lean thinking; after all, its focus is on the development of products to simplify the assembly and manufacturing (Sánchez and Pérez, 2001), nonetheless a way of eliminating waste and adding value. Thus, some of the concepts linked to lean product 
development emanated during the 1980s and 1990s from both academics and practitioners searching for better fits between NPD and downstream functions; according to Bralla (1996) this discussion, taken as a starting point by him for applying lean thinking to NPD, began before 1995. Therefore, the search for 'perfection' builds on concepts, such as QFD, Kano model and design for $\mathrm{X}$, which were developed simultaneously but separate from lean product development, while sharing the same objectives.

\section{[Insert Figure 5 about here]}

\section{Conceptualisation of Lean Product Development beyond Lean Thinking}

Though the concepts of lean thinking applied to product development may have precedent in or have been developed in parallel with other techniques and methods, most of all, lean product development should be taken as an approach to NPD. From this perspective, processes of NPD cover capturing customers' needs and technological developments to generating instructions for supply, production, assembly, distribution logistics, use and recycling; see Figure 5 for that generic process. Such processes should ensure that new products and their related processes match the resources and structures of supply chains, manufacturing and business models, including considerations for sustainability (Figueiredo and Loiola, 2012; Salgado et al., 2012). NPD should be placed in the context of (corporate and) competitive strategies, with time-to-market, including product launch and commercialisation, being dominant. Lean product development (e.g. Baines et al., 2006; Hoppmann et al., 2011; León and Farris, 2011; Siyam et al., 2015; von Würtemberg et al. 2011) aims to achieve these objectives by reducing waste. In addition, Nepal et al. (2011, p. 62) assert that the objective of a lean management structure is ensuring alignment, ownership, teamwork, communications and visibility across the NPD processes. This indicates that lean product development might be associated with different objectives presented by different 
authors. Therefore, a discussion about this approach derived from lean thinking is needed to clarify what is really new and if all the tenets are applicable to NPD.

If we equate Toyota's approach to product development as lean product development, 'setbased concurrent engineering' is a central concept, according to Ward et al. (1995, p. 44). Calling it also the 'second Toyota paradox', they describe how this principle of subsequent evaluation of design alternatives and elimination of less preferable ones leads to an effective and efficient process for product development. They announce that Toyota's approach enables reliable and efficient communication, allows better management of parallel development activities and teams, enhances organisational learning and leads to optimal designs. Fifteen years later, Raudberget (2010, p. 685) writes that the evidence until that date seems to be limited to the original case of Toyota. He adds then his own four case studies implying that the cost of products is reduced, but that the lead time for development and the use of resources increased (ibid., pp. 691-692); he also reports that these companies ponder implementing it for successive products. Whereas there is scarce evidence for set-based concurrent engineering, Pugh's controlled convergence method (Pugh, 1981) is seen as a basic tool for designers and engineers (though his thought is preceded by that of Abernathy and Rosenbloom [1969], albeit not very clearly stated). It is Pugh's method, later published in 1991, that set-based concurrent engineering mimics. Others, among them Ulrich and Eppinger (1995) and Wheelwright and Clark (1992), have also adopted this approach. Though advocated as unique by Ward et al. (1995), later in their paper (ibid., pp. 48-49) they link it to Pugh's method without mentioning that Toyota's approach is not different. Subsequent studies (e.g. Khan et al., 2011) are extending this framework of set-based concurrent engineering, though not referring to Pugh (1981) or similar works. Thus, it can be concluded that set-based concurrent engineering is not a unique feature, whereas (recent) 
works on lean product development, such as Al-Ashaab, Golob et al. (2013), Belay et al. (2014) and Mund et al. (2015), are even ignoring its heritage.

In addition to the heavily cited paper by Ward et al. (1995) about set-based concurrent engineering as a characteristic of lean product development, one of the most cited papers in this strand of research - that by Karlsson and Åhlström (1996) - addresses the implementation of lean product development in a case study. They explain that lean product development comprises numerous interrelated techniques and methods, including supplier involvement, cross-functional teams, concurrent engineering, integration (as opposed to coordination) of various functional aspects of each project, the use of a heavyweight team structure and the strategic vision and objectives for each development project. However, they (ibid., p. 285) also note that this is their own interpretation of lean product development, without any justification; surprisingly, all authors that refer to this study have accepted this particular conceptualisation. Moreover, without referring to lean product development at all an in-depth study of cases by Boer and During (2001) reveals similar aspects as being crucial to the success of a project for new products (and process innovation). Also in the early 1990s, Henke et al. (1993) and Pinto and Pinto (1990) argue that an important key to successfully developing new products is the degree of cross-functional cooperation. Furthermore, around the same time period, Brown and Eisenhardt (1995) and Clark and Wheelwright (1992) suggested that heavyweight team leaders offer improved communication, strong identification and commitment to project, and a focus on cross-functional problem solving. Moreover, the integration of various functional aspects into each project is discussed by the Project Management Institute (PMI, 1996, p. 39). In addition, Birou and Fawcett (1994, p. 4) state that suppliers have a considerable impact on NPD; they contribute to better resource utilisation, improve the technological expertise and increase network effectiveness. Curiously, Karlsson and Åhlström (1996) have not addressed waste, which is considered by 
many to be a core principle of lean product development; that differs from other propositional writings, such as Bauch (2004), Haque and James-Moore (2004a) and Oppenheim (2004), who take this principle as their starting point. Furthermore, the study by Karlsson and Åhlström (1996) has not looked at the principles, tools and metrics, which can be found in other studies about lean product development, for example da Costa et al. (2014), Haque and James-Moore (2004b) and Liker and Morgan (2006). Also, the paper by Karlsson and Åhlström (1996) does not mention set-based concurrent engineering at all. This means that the two most cited papers - Ward et al. (1995) about set-based concurrent engineering and Karlsson and Åhlström (1996) - are incomplete and do not do justice to the heritage beyond lean product development.

\section{[Insert Table 4 about here]}

\section{[Insert Figure 6 about here]}

Over the course of time, extensions have been proposed to these two conceptualisations of lean product development. Cases in point are the studies by Al-Ashaab, Golob et al. (2013) and Carleysmith et al. (2009), which include set-based concurrent engineering, product lifecycle management and design for six sigma in their approaches. Table 4 lists all these extensions. From a practical point of view, other approaches, particularly the tools they offer, could be integrated without contradicting the core objective of lean - to provide value to customers (Hines et al., 2006, pp. 872-873) and to eliminate waste (Hoppmann et al., 2009, pp. 15-16) (see Figure 6). Obviously, all these extensions over the years by other researchers, such as Carleysmith et al. (2009), Flores et al. (2010), Oehmen and Rebentisch (2010a) and Walton (1999), have moved the approach of lean product development away from its initial focus on eliminating waste and adding value to conceptualisations that cover a wider range of methods, tools and practices. For example, Lee and Chang (2010, p. 425) propose using lean six sigma for aligning business and supply chain strategies; however some of these 
researchers (e.g. Fouquet, 2007) have not integrated the analysis of waste as would naturally follow from the principles of lean thinking. Furthermore, the concept might have been adapted because authors thought they were applying lean principles for a specific cause, while not (fully) considering its objectives, principles and methods (in addition its heritage). In this context, it is not yet possible to state that lean product development is a new approach, even with its extensions; perhaps it is only the philosophy of a constant quest to eliminate waste and add value applied to NPD, something we now need to explore.

A most notable extension of conceptualisation in the retrieved papers is the connection of lean thinking to knowledge management and the product life cycle. Whereas knowledge management appears in quite a number of papers, this is mostly linked to reuse of designs at different levels (Gautam et al., 2007), modularisation (Anand and Kodali, 2008; Rossi et al., 2012, p. 6) and standardisation (Dal Forno, Forcelinni and Bornia, 2013; Dal Forno, Forcelinni, de Miranda et al., 2013; Welo and Ringen, 2015, p. 237; Welo et al., 2012, pp. 810, 2013, p. 897; Yang and Cai, 2009, p. 87 ff.). This could also be caused by the types of industries, such as the aerospace and automotive industries that are dominant in the studies (see Figure 4); these industries may have more repetitive processes than other types of industries. Such argument is related to the novelty of NPD, which is weakly developed and hardly investigated in the context of lean product development. The additional quest for connecting lean product development to life-cycle management (Dem et al., 2012, pp. 184189; Dombrowski and Schmidt, 2013; Hines et al., 2006; Maksimovic, 2013; Murman, 2008; Walton, 1999, pp. 16-18) seems mostly embedded in the aerospace industry.

\section{Is Lean Product Development the Only Way?}

So far, the concept of lean product development, whatever it covers according to specific authors, has been rooted in preceding approaches and other concepts beyond the principles of 
lean thinking; perhaps something more can be derived from its implementation and use. In this respect, many works cite as characteristics for the lean approach to NPD: the need for a heavyweight project manager (for example, Hoppmann et al., 2011, p. 7; Karlsson and Åhlström, 1996, p. 285); the need for parallel activities (e.g. Baines et al., 2006, p. 1545; Karlsson and Åhlström, 1996, p. 289; Nepal et al., 2011, p. 59); the use of multidisciplinary teams, and collaboration and integration between departments to reduce lead time of product development (for instance Karlsson and Åhlström, 1996, p. 283; Liker and Morgan, 2006, p. 13; Nepal et al., 2011, p. 62). However, the question arises whether these features for lean product development are really confined to this approach. These features cannot be considered specific for the approach of lean product development since other concepts for product development, such as multidisciplinary teams (Page, 1993), concurrent engineering (Kusiak and Park, 1990; Miles, 1990) and stage-gate processes (Cooper, 1983), have been related to the same characteristics; also, Boer and During (2001, pp. 104-105), Meybodi (2013, p. 364-365) and Rozenfeld et al. (2006, p. 38) refer to similar characteristics. For those that are interested, concurrent engineering appeared first as simultaneous engineering (Kusiak and Park, 1990, p. 1883). To support this notion Meybodi (2013, p. 373) shows in a statistical study that similarities exist between principles for lean manufacturing and concurrent engineering for a majority of factors. However, it does not account for the characteristics of NPD being iterative, as discussed in beginning of the previous section 'Examining the Basic Tenets of Lean Product Development', and, therefore, being more similar to a job shop than a production line or manufacturing cells. One of the flaws in Meybodi's work is that the two-way communication is identical (for manufacturing one way is the primary process and the other way is control information, whereas for NPD the twoway is about product specifications). Separate from works that are flawed in reasoning, both the implementation and use of lean product development falls back on determinants for 
success that are not exclusive - perhaps not even for NPD - and deploys concepts, such as concurrent engineering and stage-gate models, that came about independently.

From the perspective of standardisation and simplification in NPD (Haque and James-Moore, 2004a, pp. 9, 16) the same applies. In this respect, Baines et al. (2006, p. 1546) state that the standardisation of knowledge and information management for the adoption of lean product development has yet to be defined. If we look at companies that use total quality management for all processes, this might bring about the need for standardisation and simplification. Logically, this notion might only apply when the degree of novelty for NPD is relatively low. This is supported by Stockton (1983, p. 16) who indicates the difficulties involved in standardising NPD. Some authors, such as Bertelli and Loureiro (2015, p. 50) and Hines et al. (2004, p. 1007), view total quality management as a technique related to lean thinking in NPD, albeit sometimes somewhat implicitly; but they do not seem to be aware that total quality management was practised well before lean production, and lean product development for that matter. In addition to total quality management, with its drive for standardisation and simplification, some authors (e.g. Liker and Morgan, 2011, p. 16; Powell et al., 2014, p. 574) present modular design as a method associated with lean thinking in NPD. Although modular design might facilitate lean product development, its relevance to product development and manufacturing already appears in the work of Bikker and van der Heyden (1987), Kamarkar and Kubat (1987) and De Toni and Zipponi (1991). Modularity often links to product families consisting of standardised assemblies, components and parts (Dekkers et al., 2013, p. 322); there is a strong relationship with product platforms (Meyer and Utterback, 1993). Modular design, product platforms and standardisation are means to an end for NPD and might facilitate lean product development but are not exclusive to it. Thus, it can be concluded that the discussion about standardisation and simplification applying to NPD dates also back beyond the conception of lean product development. 


\section{[Insert Table 5 about here]}

When lean product development is compared with other recent approaches (Rozenfeld et al., 2006, p. 33), e.g. design for six sigma, the capability maturity model and product life-cycle management, it can be seen that these are complementary; see Table 5. For example, the focus of design for six sigma is optimisation of design solutions mainly by using statistical tools, which can be used in the lean approach, but with the focus on waste elimination or value aggregation. Similar to product life-cycle management, lean thinking seeks the integration of all stages across the product life cycle, including production and organisational learning (Hines et al., 2006, p. 882). This carries some similarities to the capability maturity model developed in the late 1980s by the Software Engineering Institute; this model is organised into five maturity levels (Paulk, 1993, p. 246; Paulk et al., 1993, p. 21). Nevertheless, when analysing the maturity levels it emerges that some of the principles are similar to lean product development and were created during the 1980s and 1990s with the same objective. However, the union of these approaches brings the idea of increasing the range of tools used to solve NPD problems, which are also not new. Thus, we can infer that lean thinking applied to product development is an evolution of the previous NPD approaches with the inclusion of principles to eliminate waste and to enhance value; however, this does make the concept of lean product development neither unique nor new.

\section{Some Final Thoughts}

After looking at the principles, methods and tools of lean product development in relation to other approaches available, the question arises: based on the preceding critical review, what makes lean product development stand apart? In its original conception, dating back to Womack and Jones's (1996) work on the principles of lean thinking, the foremost added value of lean product development is its focus on searching for value and eliminating waste. 
Over the course of time, authors have added other methods, tools and principles, increasing its scope but also causing confusion about the delineation of lean product development relative to other approaches. The shifting content and differing interpretations of scope do not allow systematic evaluation of its tenets, thus not meeting the criterion of falsifiability of constructs (see Bacharach, 1989, p. 503) across studies. Even studies themselves have not included the notion of falsifiability, e.g. Khan et al. (2011), Tyagi et al. (2015) and Wang, Ming et al. (2011), not least the original study by Womack and Jones (1996). Neither does such divergent adoption of the concept of lean product development lead to which theoretical question will be addressed, akin to Sutton and Staw's (1995, p. 373) remark. Therefore, our first recommendation is that if studies are undertaken on lean product development, they should clearly identify its principles and its delineation from other approaches; authors doing so should also be clarifying why they have expanded on the original conceptualisation rather than including additional tools and methods without rationale.

Rather, based on these extensions that are put forward with poor or non-reasoning, one cannot come to any other conclusion than that lean product development in its original conception is simply inadequate. If the two main principles of eliminating waste and searching out value for customers would suffice, no extensions and additions need to be proposed. Thus, the mere fact that numerous authors have included other approaches indicates the inadequacy of lean product development as an integral approach. Then it shares the same fate as product life-cycle management, product platforms, stage-gate models, etc.; all describe aspects of NPD but never its entirety. This is exemplified by 22 publications in our sample that refer to other methods for NPD (see Table 6); noteworthy is Bjarnoe's (2006, p. 44) remark that lean product development seems to deploy methods and tools used for the development of the P-51 Mustang fighter during the Second World War. In the set of 22 publications, the only comparative study is the propositional paper by Ćatić and Vielhaber 
(2011); this intimates that the 21 other ones have attempted to integrate other approaches into NPD for the purpose of conceptualising of lean product development. Antagonistic to our stance about lean product development that means that the extensions can be useful for managing NPD better, albeit that it may lead to further confusion as to what lean product development is standing for (perhaps even leading to more papers in the future adding to the befogging about its conceptualisation).

\section{[Insert Table 6 about here]}

\section{Implications for Practice}

All these discussions have implications for how NPD should be managed. NPD should be considered in a broader context that covers the corporate strategy for product development and marketing, including business models, competitive strategy, human resources and process performance (e.g. MacCormack et al., 2012; Sivasubramaniam et al., 2012; Trim and Pan, 2012; Trimi and Berbegal-Mirabent, 2012). In addition, there are many alternative approaches, e.g. sustainable NPD (Gmelin and Seuring, 2014) and Design for X (Meerkamm, 1994), and methods and tools, for example QFD and failure mode effect analysis (Chai and Xin, 2006). So, both arguments allow managers for new product (and service) development to select from a wider pallet of methods and approaches to enhance performance of R\&D and to connect better to manufacturing (including supply chains). How lean thinking during NPD benefits overall performance in comparison to other approaches remains elusive; however, the conceptualisation of lean product development could be framed within an integral approach to the rationalisation of NPD (see Figure 7). Therefore, managers will have to rely on their intuition and experience for setting out appropriate approaches to NPD and how lean product development needs to be complemented to arrive at an integral approach based on Figure 7. 


\section{[Insert Figure 7 about here]}

Perhaps of interest to practitioners is that some studies have mentioned bottleneck management as key to increasing efficiency. By Baines et al. (2007, p. 1599) it is merely touched on in the context of managing workflows; and by Wang, Quesada-Pineda et al. (2011) in an implicit manner. However, studies by Beauregard, Bhuiyan and Thomson (2008, p. 1520) and Beauregard, Thomson and Bhuiyan (2008, pp. 20, 25) take bottleneck management as their starting point for the value stream, albeit limited to certification processes in NPD. Nevertheless, these two studies are less extensive than that by Hinckeldeyn et al. (2014), who examine different bottleneck strategies and their effects on performance of NPD; the mention by Morgan (2002, p. 333) of flexible capacity is only one of the strategies, as is Choothian's $(2014$, p. 41) reference to queue management for controlling bottlenecks. Consequently, practitioners in product development may benefit from the outcomes of these initial studies into bottleneck management to increase throughput. Nevertheless, the 'lesson' from applying lean thinking to NPD is that of organisational learning. Thus, actions to reduce or eliminate waste and add value during the NPD process should be part of continuous improvement. Such thinking has strong parallels with organisational learning, for example, Adams et al. (1998), Adams and Lamont (2003) and Hoe (2007). Hence, the frameworks for lean product development proposed in the literature and in Figure 7 may assist companies in producing an environment that is adequate for increasing their NPD performance.

\section{Implications for Research}

This positive connotation comes along with some profound limitations that have been highlighted during this review. The first is the degree of novelty. The concept of lean product development has not been adequately placed on the dichotomy of incremental versus radical 
innovation. Particularly, its reliance on the elimination of waste implies that it only applies to recurrent processes, which can only be found through standardisation and simplification. It is incremental innovation in which this is possible and it rules out the use of lean thinking for radical innovation, though different findings were reported. The same applies to value creation for customers, albeit possibly to a lesser extent. The second limitation is the reasoning for the feasibility of lean thinking for product development. Most writings assume that NPD is similar to the recurrent processes of manufacturing, particularly production lines. We have already demonstrated that NPD resembles more a job shop than line production (see beginning of the section 'Examining the Basic Tenets of Lean Product Development'). The question is then how to extend lean thinking to a job-shop environment. Such a quest should also go beyond oversimplification and incorrect comparisons; Meybodi's (2013) work is a case in point. These two limitations need to be accounted for, which is poorly done in the retrieved papers on lean product development.

Taking these two limitations into account, further research is necessary on comparing lean product development with other approaches regarding the rationalisation of the product development process. Thus, future research to demonstrate the relationships between lean product development and, for example, product platforms, modular design, capability maturity model for NPD may well provide results that show how much is the degree of similarity between lean product development and these approaches as analysed by Meybodi's (2013) work about the approach of concurrent engineering. Also, the framework in Figure 7 could assist in framing future research in the context of rationalisation and performance. Furthermore, more research is necessary to analyse the applicability of production management principles to engineering management, similar to Hinckeldeyn et al. (2015). Since performance measurement applies to NPD irrespective of approach, this research will make it possible to verify the tenets of lean product development. 
These implications for research result in agendas for two different groups of researchers in addition to the individual observations and inferences throughout the manuscript; the first group, doctoral students and early career researchers, may benefit from our findings in four ways. First, this review provides insight into which concepts of lean product development have been developed before or in parallel to the application of lean thinking to NPD. Examples are set-based concurrent engineering that preceded the controlled convergence method and the method of value stream mapping that rooted in the ASME process-mapping standard. Such insight will avoid claims that concepts are new, while they have been in existence before under different labels, and they will contribute to a better conceptualisation of lean product development. To this end, our manuscript offers a wide range of sources, including lesser-known sources with differing views on the conceptualisation of new product development, such as the writing by Bjarnoe (2006), so that research projects with a narrow focus can build on relevant extant literature. Second, studies with a clear scope and narrow focus should delineate the conceptualisation of lean product development from other approaches that can be used complementary or conjointed to improve the performance of NPD. This holds also true for specific constructs, such as value, that have a different meaning for manufacturing than for NPD. Third, the specific characteristics of NPD in comparison to manufacturing should be taken into account. These include the degree of novelty, the iterations inherent to NPD, and the necessity for variability in product development in contrast to manufacturing (for part contradicting the quest for increased productivity of NPD). Fourth, integrative studies relating lean product development to complementary approaches for NPD should be welcomed, too. This should include comparative studies vetting lean product development against other specific approaches to NPD. This review, particularly Figure 7, may provide inspiration for this new strand of research. Thus, doctoral students and early career researchers can use this manuscript as a point of reference, have 
insight into the historical development of lean product development and delineate the concept from other approaches to new product development.

In addition to these four points for doctoral students and early career researchers, those that are more advanced in their careers or are managing research programmes could take advantage of the following five notions. Whereas our review is confined to product development - see subsection 'Retrieval of Publications' about the exclusion criteria - a similar undertaking may be considered for construction projects, new service development and project management in general. In this respect, some literature reviews about lean thinking to other domains already exist; for example, the paper by Jørgensen and Emmitt (2008) already critically reviews the application of lean manufacturing to construction, but does so as a narrative overview (see Green et al. [2006, p. 103] for this classification). Thus, such papers lack a systematic approach to the literature review, which means that not necessarily are all relevant sources are covered, and they are not aiming at lean product development or directly related domains. Such reviews would reveal whether findings in this paper are applicable to a broader context. Moreover, a discourse should be started about whether principles of lean product development are confined to the five (adapted) principles of lean thinking (derived from Womack and Jones [1996, pp. 16-26]), the thirteen principles of Liker and Morgan (2006, pp. 10-15) or any other set of principles. This debate could contribute to better delineation of what lean product development constitutes and, therefore, contribute to benchmarking empricial studies with the aim of reaching more definite and more focused inferences about the added value of the conceptualisation of lean product development. Over and above this, attention should be paid to how the analogy from manufacturing can be effectively deployed to NPD in this discourse. As aluded to in the introduction of the section 'Examining the Basic Tenets of Lean Product Development' and when discussing the principle of flow, the question could be raised how NPD should be 
characterised: as job-shop or as production line? And does the iterative character of these processes, sometimes excarbarated by the degree of novelty, allow this analogy? In this respect it is worth mentioning that Hodgson (1993, pp. 18-20) remarks that playing with metaphors means approaching reality from various perspectives, and recognising that concepts have subjective interpretations as well as inevitably a social and academic history and context. Whereas our review contains a partial account of academic thought and the subjective interpretations resulting in a somewhat skeptic stance, the discussion about how manufacturing and product development compare for the purpose of applying lean thinking has not been settled, yet. Furthermore, systems engineering companies - aerospace and automotive - are considered more immature for implementing lean practices and capabilities for knowledge management (see subsection 'Descriptive Results of Systematic Literature Review'). This is also indirectly confirmed by Figure 4, which shows the dominant industries investigated are aerospace and automotive. However, an explanation for this phenomenon is missing; is it because systems engineering requires a more rigid approach to NPD, is it because these industries are regulated or is it that organisational hierarchy is more dominant? Not limited to these three questions, further research should shed light on this intriguing finding. Finally, a dialogue should be started about holistic approaches to NPD and how lean product development can be positioned within these. Throughout the paper we came across holistic approaches but these do not capture lean product development and, conversely, papers about lean product development mention sometimes include additional tools, methods and processes but are never complete either. However, practitioners need a holistic view to manage NPD and related processes (for example, Figure 5 and 7). Thus, these five notions aim at stimulating critical discussion about (the delineation of) lean product development and its applications. 
Further research is also necessary because of the limited scope of research methods used for the study of lean product development. Most of the retrieved papers are case studies and, in addition, they are mostly descriptive. This does not necessarily lead to insight. In particular, in these case studies the falsifiability of lean product development is not taken into account. This means that it is difficult to discern the tenets of lean product development versus those cases where it is absent (akin to the call for maximum variation case studies by Flyvbjerg [2006, p. 230]). Because of the originally 'limited scope' of lean product development it will be even more difficult to distinguish its effects as part of an integral approach for NPD, where other approaches, methods and tools also contribute to overall performance. Multiple methods are necessary to assert the contribution of lean product development, following Weick's (1995) arguments, albeit that all studies need to contribute collectively to rigorous evidence.

Putting it all together, so far, the concept of lean product development brings little to the table beyond common sense and concepts that already existed at its time of conception and concepts that came about later. In this sense, lean product development is an amalgamation of tools and methods that is neither unique nor complete. Whereas it might have some advantages to bring together more methods and tools than those related to the principles of elimination of waste and searching for value for customers, that should not be presented as lean product development. For these reasons, it becomes necessary that researchers into lean product development demonstrate knowledge about its origins and present appropriately the heritage of all frameworks they use and recognise the extant contributions (it would be helpful if editors and reviewers would stimulate this 'literature sensitivity' as [minimal] professional knowledge). 
This brings us back to the starting point of this paper: why do academics present lean product development as something new or different? Why has this approach been so readily embraced by the 'product development' community? Is it a matter of management fashions, as Abrahamson and Fairchild (1999) contend for generic attitudes of researchers towards managerial concepts? Or is it simply that academics have to 'sell' themselves to practitioners, as Micklethwait and Wooldridge (1996) assert? It is for the reader to decide. However, it is clear from our writing that there is nothing new under the sun for lean product development! 


\section{References}

Abernathy, W.J. and Rosenbloom, R.S. (1969). Parallel Strategies in Development Projects. Management Science, 15(10), pp. B-486-B-505, doi: 10.1287/mnsc.15.10.B486.

Abrahamson, E. and Fairchild, G. (1999). Management fashion: Lifecycles, triggers, and collective learning processes. Administrative Science Quarterly, 44(4), pp. 708-740, doi: $10.2307 / 2667053$.

Adams, G.L. and Lamont, B.T. (2003). Knowledge management systems and developing sustainable competitive advantage. Journal of Knowledge Management, 7(2), pp. 142154, doi: 10.1108/13673270310477342.

Adams, M.E., Day, G.S. and Dougherty, D. (1998). Enhancing New Product Development Performance: An Organizational Learning Perspective. Journal of Product Innovation Management, 15(5), pp. 403-422, doi: 10.1111/1540-5885.1550403.

Al-Ashaab, A., Golob, M., Attia, U.M., Khan, M., Parsons, J., Andino, A., Perez, A., Guzman, P., Onecha, A., Kesavamoorthy, S., Martinez, G., Shehab, E., Berkes, A., Haque, B., Soril, M. and Sopelana, A. (2013). The transformation of product development process into lean environment using set-based concurrent engineering: A case study from an aerospace industry. Concurrent Engineering, doi: $10.1177 / 1063293 \times 13495220$.

Amin, M.A., Karim, M.A. and Yarlagadda, P.K.D.V. (2010). Assessing the leanness in product design : a model for planned design reuse. In Butee, S., Sapsamantemsiri and Yarlagadda, P.K. (eds.), 10th Global Congress on Manufacturing and Management Bangkok.

Anand, D.U., Janakiraman, S.R. and and Sethukannan, V.S. (2009). Lean Product Development - Redefining the Indian Automotive Product Development Process using Lean Framework. Warrendale, PA: Society of Automotive Engineers.

Anand, G. and Kodali, R. (2008). Development of a Conceptual Framework for Lean New Product Development Process. International Journal of Product Development, 6(2), pp. 190-224, doi: 10.1504/IJPD.2008.01924.

Anderson, D.M. (1997). Agile Product Development for Mass Customization Chicago: Irwin Professional Publishing.

Bacharach, S.B. (1989). Organizational Theories: Some Criteria for Evaluation. Academy of Management Review, 14(4), pp. 496-151, doi: 10.5465/AMR.1989.4308374.

Baines, T., Lightfoot, H., Williams, G.M. and Greenough, R. (2006). State-of-the-art in lean design engineering: A literature review on white collar lean. Proceedings of the Institution of Mechanical Engineers, Part B: Journal of Engineering Manufacture, 220(9), pp. 1539-1547, doi: 10.1243/09544054jem613.

Baines, T.S., Williams, G.M., Lightfoot, H.W. and Evans, S. (2007). Beyond theory: An examination of lean new product introduction practices in the UK. Proceedings of the Institution of Mechanical Engineers, Part B: Journal of Engineering Manufacture, 221(11), pp. 1593-1600, doi: 10.1243/09544054jem871.

Ballé, F. and Ballé, M. (2005). Lean Development. Business Strategy Review, 16(3), pp. 1722, doi: 10.1111/j.0955-6419.2005.00369.x.

Bañuelas, R. and Antony, J. (2003). Going from six sigma to design for six sigma: an exploratory study using analytic hierarchy process. The TQM Magazine, 15(5), pp. 334344, doi: 10.1108/09544780310487730. 
Bassler, D., Oehmen, J., Seering, W. and Ben-Daya, M. (2011). A comparison of the integration of risk management principles in product development approaches. In Culley, S.J., Hicks, B.J., Mcaloone, T.C., Howard, T.J. and Cantemessa, M. (eds.), 18th International Conference on Engineering Design. Lyngby/Copenhagen: The Design Society.

Bauch, C. (2004). Lean Product Development: Making Waste Transparent. Department of Mechanical Engineering/Department of Product Development. Munich: Massachusetts Institute of Technology/Technical University of Munich.

Baxter (1995). Product Design: Practical methods for the systematic development of new products London: Chapman \& Hall.

Beauregard, Y., Bhuiyan, N. and Thomson, V. (2008). Lean Engineering Systems for Product Development in the Aerospace Industry. In Fowler, J. and Mason, S. (eds.), Industrial Engineering Research Conference. Vancouver, BC.

Beauregard, Y., Bhuiyan, N. and Thomson, V. (2011). Post-Certification Engineering Taxonomy and Task Value Optimization in the Aerospace Industry. Engineering Management Journal, 23(1), pp. 86-100, doi: 10.1080/10429247.2011.11431888.

Beauregard, Y., Thomson, V. and Bhuiyan, N. (2008). Lean engineering logistics: load leveling of design jobs with capacity considerations. Canadian Aeronautics and Space Journal, 54(2), pp. 19-30, doi: 10.5589/q08-006.

Becker, J.M.J. and Wits, W.W. (2015). Enabling Lean Design Through Computer Aided Synthesis: The Injection Moulding Cooling Case. Procedia CIRP, 37, pp. 260-264, doi: 10.1016/j.procir.2015.08.057.

Belay, A.M., Welo, T. and Helo, P. (2014). Approaching lean product development using system dynamics: investigating front-load effects. Advances in Manufacturing, 2(2), pp. 130-140, doi: 10.1007/s40436-014-0079-9.

Bertelli, C.R. and Loureiro, G. (2015). Quality Problems in Complex Systems even Considering the Application of Quality Initiatives during Product Development. In Curran, R., Wognum, N., Borsato, M., Stjepandić, J. and Verhagen, W.J.C. (eds.), Transdisciplinary Lifecycle Analysis of Systems. Amsterdam: IOS Press, pp. 40-51.

Bikker, H. and Heyden, W.v.d. (1987). Systematic Product Breakdown as a major tool for productivity improvement. International Journal of Production Research, 25(11 ), pp. 1635-1644, doi.

Birou, L.M. and Fawcett, S.E. (1994). Supplier Involvement in Integrated Product Development: A Comparison of US and European Practices. International Journal of Physical Distribution \& Logistics Management, 24(5), pp. 4-14, doi: 10.1108/09600039410063982.

Bjarnoe, O.-C. (2006). Lean thinking in product development. In Malmberg, P. (ed.), European Productivity Conference. Tampere: Yrittäjäruuvi Oy.

Boer, H. and During, W.E. (2001). Innovation, what innovation? A comparison between product, process and organisational innovation. International Journal of Technology Management, 22(1/2/3), pp. 83-107, doi: 10.1504/IJTM.2001.002956.

Boothroyd, G. (1987). Design for assembly-The key to design for manufacture. The International Journal of Advanced Manufacturing Technology, 2(3), pp. 3-11, doi: $10.1007 / \mathrm{bf0} 2601481$.

Bralla, J.G. (1996). Design for Excellence New York: McGraw-Hill. 
Brown, S.L. and Eisenhardt, K.M. (1995). Product Development: Past Research, Present Findings, and Future Directions. Academy of Management Review, 20(2), pp. 343-378, doi: 10.5465/amr.1995.9507312922.

Browning, T.R. (2000). Value-based product development: refocusing lean. IEEE Engineering Management Society. Albuquerque, NM: IEEE.

Browning, T.R. (2003). On Customer Value and Improvement in Product Development Processes. Systems Engineering, 6(1), pp. 49-61, doi: 10.1002/sys.10034.

Bullinger, H.-J., Fähnrich, K.-P. and Meiren, T. (2003). Service engineering-methodical development of new service products. International Journal of Production Economics, 85(3), pp. 275-287, doi: 10.1016/S0925-5273(03)00116-6.

Cabello, A., Flores, K., Flores, M., Khan, M. and Al-Ashaab, A. (2012). An analysis of methods to achieve robustness towards a lean product development process. In Katzy, B., Holzmann, T., Sailer, K. and Thoben, K.-D. (eds.), 18th International Conference on Engineering, Technology and Innovation. Munich: IEEE.

Carleysmith, S.W., Dufton, A.M. and Altria, K.D. (2009). Implementing Lean Sigma in pharmaceutical research and development: a review by practitioners. $R \& D$ Management, 39(1), pp. 95-106, doi: 10.1111/j.1467-9310.2008.00542.x.

Ćatić, A. and Sobek II, D.K. (2013). Development of Key Performance Indicators for Knowledge Management. In Krishnamurty, A. and Chan, W.K.V. (eds.), Industrial and Systems Engineering Research Conference. San Juan (Puerto Rico).

Ćatić, A. and Vielhaber, M. (2011). Lean Product Development: Hype or sustainable new paradigm? In Culley, S.J. and Hicks, B.J.M., T.C.; Howard, T.J. \& Clarkson, P.J. (eds.), 18th International Conference on Engineering Design. Lyngby.

Chai, K.H. and Xin, Y. (2006). The Application of New Product Development Tools in Industry: The Case of Singapore. IEEE Transactions on Engineering Management, 53(4), pp. 543-554, doi: 10.1109/TEM.2006.883708.

Chan, L.-K. and Wu, M.-L. (2002). Quality function deployment: A literature review. European Journal of Operational Research, 143(3), pp. 463-497, doi: 10.1016/S03772217(02)00178-9.

Chao, L.P. and Ishii, K. (2006). Design process error-proofing: Failure modes and effects analysis of the design process. Journal of Mechanical Design, 129(5), pp. 491-501, doi: 10.1115/1.2712216.

Chase, J. (2000). Measuring Value in Product Development. Working Papers. Cambridge, MA: Massachusetts Institute of Technology.

Choothian, W. (2014). A study of the application of lean practices to new product development processes. Industrial Engineering. Corvallis, OR: Oregon State University.

Clark, K.B. and Fujimoto, T. (1991). Product Development Performance: Strategy, Organization, and Management in the World Auto Industry Boston, MA: Harvard Business School Press.

Clark, K.B. and Wheelwright, S.C. (1992). Organizing and Leading "Heavyweight" Development Teams. California Management Review, 34(3), pp. 9-28, doi: $10.2307 / 41167421$.

Cohen, L. (1988). Quality Function Deployment: An Application Perspective from Digital Equipment Corporation. National Productivity Review, 7(3), pp. 197-208, doi: 10.1002/npr.4040070302. 
Conn, V.S., Valentine, J.C., Cooper, H.M. and Rantz, M.J. (2003). Grey Literature in MetaAnalyses. Nursing Research, 52(4), pp. 256-261, doi.

Cooper, R.G. (1983). A Process Model for Industrial New Product Development. IEEE Transactions on Engineering Management, EM-30(1), pp. 2-11, doi: 10.1109/TEM.1983.6448637.

Cooper, R.G. (1990). Stage-gate systems for managing new products. Business Horizons, 33(3), pp. 44-54, doi.

Cooper, R.G., Edgett, S.j. and Kleinschmidt, E.J. (2001). Portfolio Management for New Products Cambridge, MA: Perseus Publishing.

Costa, J.M.H., Rossi, M., Rebentisch, E., Terzi, S., Taisch, M. and Nightingale, D. (2014). What to Measure for Success in Lean System Engineering Programs? Procedia Computer Science, 28, pp. 789-798, doi: 10.1016/j.procs.2014.03.094.

Cronin, P., Ryan, F. and Coughlan, M. (2008). Undertaking a literature review: a step-by-step approach. British Journal of Nursing, 17(1), pp. 38-43, doi: 10.12968/bjon.2008.17.1.28059.

Cusumano, M.A. and Nobeoka, K. (1998). Thinking Beyond Lean: How Multi-Project Management is Transforming Toyota and Other Companies New York: The Free Press.

da Costa, J.M.H., Oehmen, J., Rebentisch, E. and Nightingale, D. (2014). Toward a better comprehension of Lean metrics for research and product development management. $R \& D$ Management, 44(4), pp. 370-383, doi: 10.1111/radm.12074.

Dal Forno, A.J. and Forcellini, F.A. (2013). Lean product development - principles and practices. Product: Management \& Development, 10(2), pp. 131-143, doi: 10.4322/pmd.2013.007.

Dal Forno, A.J., Forcellini, F.A. and Bornia, A.C. (2013). Lean Product Development: Benchmarking in Brazilian Companies. 22nd International Congress of Mechanical Engineering. Ribeirão Preto.

Dal Forno, A.J., Forcellini, F.A., de Miranda, R.G. and Bornia, A.C. (2013). Use of the Lean Product Development Approach by Capital Goods Companies in Brazil. IFAC Proceedings Volumes, 46(24), pp. 553-558, doi: 10.3182/20130911-3-BR-3021.00005.

Dal Forno, A.J., Pereira, F.A., Forcellini, F.A. and Kipper, L.M. (2014). Value Stream Mapping: a study about the problems and challenges found in the literature from the past 15 years about application of Lean tools. The International Journal of Advanced Manufacturing Technology, 72(5), pp. 779-790, doi: 10.1007/s00170-014-5712-z.

Dal Forno, A.J., Serapiao, L.F. and Forcellini, F.A. (2011). Brazilian automotive industry trends in lean product development practices. XVII International Conference on Industrial Engineering and Operations Management. Belo Horizonte.

Darwish, M., Shehab, E., Al-Ashaab, A. and Haque, B. (2010). Value stream mapping and analysis of product development (engineering) processes. 8th International Conference on Manufacturing Research. Durham.

De Toni, A. and Zipponi, L. (1991). Product Standardisation and Process Similitude. Integrated Manufacturing Systems, 2(1), pp. 23-29, doi: 10.1108/09576069110005957.

Dekkers, R. (2010). Research at the Innovative Manufacturing Research Centres: Analysis from the mid-term review of the Innovative Manufacturing Programme. Journal of Manufacturing Technology Management, 21(1), pp. 63-99, doi: 10.1108/17410381011011498.

Dekkers, R. (2015). Applied Systems Theory Cham: Springer. 
Dekkers, R., Chang, C.M. and Kreutzfeldt, J. (2013). The interface between "Product Design and Engineering" and manufacturing: A review of the literature and empirical evidence. International Journal of Production Economics, 144(1), pp. 316-333, doi: 10.1016/j.ijpe.2013.02.020.

Dem, A.C., Pretorius, J.H.C. and Kruger, D.J. (2012). Application of lean product development at a manufacturing organisation: a case study. In Schutte, C.S.L. (ed.), 42nd International Conference on Computers \& Industrial Engineering. Cape Town.

Dombrowski, U. and Schmidt, S. (2013). Integration of design for X approaches in the concept of lean design to enable a holistic product design. IEEE International Conference on Industrial Engineering and Engineering Management. Bangkok: IEEE.

Dombrowski, U., Schmidt, S. and Schmidtchen, K. (2014). Analysis and Integration of Design for X Approaches in Lean Design as basis for a Lifecycle Optimized Product Design. Procedia CIRP, 15, pp. 385-390, doi: 10.1016/j.procir.2014.06.023.

Dombrowski, U. and Zahn, T. (2011). Design of a lean development framework. IEEE International Conference on Industrial Engineering and Engineering Management. Singapore: IEEE.

Dooley, K., Subra, A. and Anderson, J. (2001). Maturity and its impact on new product development project performance. Research in Engineering Design, 13(1), pp. 23-29, doi: $10.1007 / \mathrm{s} 001630100003$.

El-Sayed, M. (2010). Lean Design for Integrated Product Realization. SAE International Journal of Materials and Manufacturing, 3(1), pp. 194-201, doi: 10.4271/2010-010400.

El-Sayed, M. and El-Sayed, J. (2012). Balancing Manufacturability and Performance Attributes in Lean Design. SAE International Journal of Materials and Manufacturing, 5(1), pp. 174-182, doi: 10.4271/2012-01-0512.

El-Sayed, M.E.M. (2012). Implementation of Lean Tools and Methodologies in Design. ASME International Mechanical Engineering Congress and Exposition. Houston, TX: ASME.

Endris, K., Khan, M.S. and Arias, A.B. (2012). Advanced process planning in lean product and process development. In Katzy, B., Holzmann, T., Sailer, K. and Thoben, K.-D. (eds.), 18th International Conference on Engineering, Technology and Innovation. Munich: IEEE.

Evans, J.H. (1959). Basic Design Concepts. Journal of the American Society for Naval Engineers, 71(4), pp. 671-678, doi: 10.1111/j.1559-3584.1959.tb01836.x.

Figueiredo, P.S. and Loiola, E. (2012). Enhancing New Product Development (NPD) Portfolio Performance by Shaping the Development Funnel. 2012, 7(4), pp. 20-35, doi: $10.4067 / \mathrm{s} 0718-27242012000400002$.

Flores, M., Cabello, A., Torredemer, L., Agrawal, M., Keast, J., Terzi, S. and Sopelana, A. (2011). Do enterprises implement a process architecture towards Lean in product development? A comparative study among large and small firms. In Thoben, K.-D., Stich, V. and Imtiaz, A. (eds.), 17th International Conference on Concurrent Enterprising. Aachen: IEEE.

Flores, M., Flores, K., Cabello, A., Terzi, S. and Rossi, M. (2012). Understanding the approaches to create a process architecture for lean thinking. In Katzy, B., Holzmann, T., Sailer, K. and Thoben, K.-D. (eds.), 18th International Conference on Engineering, Technology and Innovation. Munich: IEEE. 
Flores, M., Klinke, S., Tucci, C., Terzi, S., Al-Ashaab, A. and Sopelana, A. (2010). Identifying Lean Thinking Measurement Needs and Trends in Product Development: Evidence from the Life Sciences Sector in Switzerland. In Pokojski, J., Fukuda, S. and Salwiński, J. (eds.), New World Situation: New Directions in Concurrent Engineering (Proceedings of the 17th ISPE International Conference on Concurrent Engineering). London: Springer London, pp. 357-365.

Flores, M., Torredemer, L., Cabello, A., Agrawal, M., Flores, K. and Tucci, C. (2012). Understanding Customer Value and Waste in Product Development: Evidence from Switzerland and Spain. In Katzy, B., Holzmann, T., Sailer, K. and Thoben, K.-D. (eds.), 18th International Conference onEngineering, Technology and Innovation. Munich: IEEE.

Flyvbjerg, B. (2006). Five Misunderstandings About Case-Study Research. Qualitative Inquiry, 12(2), pp. 219-245, doi: 10.1177/1077800405284363.

Fouquet, J.-B. (2007). Design for Six Sigma and Lean Product Development : Differences, Similarities and Links. Asian Journal on Quality, 8(3), pp. 23-34, doi: 10.1108/15982688200700023.

Freire, J. and Alarcón, L.F. (2002). Achieving Lean Design Process: Improvement Methodology. Journal of Construction Engineering and Management, 128(3), pp. 248256, doi: 10.1061/(ASCE)0733-9364(2002)128:3(248).

Furian, R., von Lacroix, F., Stokic, D., Correia, A., Grama, C., Faltus, S., Maksimovic, M., Grote, K.-H. and Beyer, C. (2013). Knowledge Management in Set Based Lean Product Development Process. In Emmanouilidis, C., Taisch, M. and Kiritsis, D. (eds.), Advances in Production Management Systems. Competitive Manufacturing for Innovative Products and Services: IFIP WG 5.7 International Conference, APMS 2012, Rhodes, Greece, September 24-26, 2012, Revised Selected Papers, Part I. Berlin, Heidelberg: Springer Berlin Heidelberg, pp. 368-375.

Furuhjelm, J., Swan, H. and Tingström, J. (2011). Creating Value through Lean Product Development - Applying Lean Principles. In Culley, S.J., Hicks, B.J., Mcaloone, T.C., Howard, T.J. and Clarkson, P.J. (eds.), 18th International Conference on Engineering Design. Lyngby/Copenhagen.

Gautam, N., Chinnam, R.B. and Singh, N. (2007). Design reuse framework: a perspective for lean development. International Journal of Product Development, 4(5), pp. 485-507, doi: 10.1504/IJPD.2007.013044.

Gershenson, J.K. and Pavnaskar, S.J. (2003). Eight Basic Lean Product Development Tools. In Folkeson, A., Gralen, K., Norell, M. and Sellgren, U. (eds.), 14th International Conference on Engineering Design. Stockholm.

Gingnell, L., Ericsson, E. and Sörqvist, L. (2012). Swedish Lean Product Development Implementation. ASQ World Conference on Quality and Improvement. Anaheim, CA.

Gmelin, H. and Seuring, S. (2014). Determinants of a sustainable new product development. Journal of Cleaner Production, 69, pp. 1-9, doi: 10.1016/j.jclepro.2014.01.053.

Graebsch, M., Seering, W.P. and Lindemann, U. (2007). Assessing Information Waste in Lean Product Development. In Bocquet, J.-C. (ed.), 16th International Conference of Engineering Design. Paris: ICED.

Green, B.N., Johnson, C.D. and Adams, A. (2006). Writing narrative literature reviews for peer-reviewed journals: secrets of the trade. Journal of Chiropractic Medicine, 5(3), pp. 101-117, doi: 10.1016/S0899-3467(07)60142-6. 
Greenhalgh, T. and Peacock, R. (2005). Effectiveness and efficiency of search methods in systematic reviews of complex evidence: audit of primary sources. British Medical Journal, 331(7524), pp. 1064-1065, doi: 10.1136/bmj.38636.593461.68.

Gremyr, I. and Fouquet, J.-B. (2012). Design for Six Sigma and lean product development. International Journal of Lean Six Sigma, 3(1), pp. 45-58, doi: $10.1108 / 20401461211223722$.

Gudem, M., Steinert, M., Welo, T. and Leifer, L. (2013). Redefining customer value in lean product development design projects. Journal of Engineering, Design and Technology, 11(1), pp. 71-89, doi: 10.1108/17260531311309143.

Gudem, M., Steinert, M., Welo, T. and Leifer, L.J. (2011). Customer value is not a numberinvestigating the value concept in lean Product Development. In Culley, S.J., Hicks, B.J., Mcaloone, T.C., Howard, T.J. and Dong, A. (eds.), 18th International Conference on Engineering Design. Lyngby.

Gudem, M. and Welo, T. (2010). From Lean Product Development to Lean Innovation: Finding Better Ways of Satisfying Customer Value. In Pokojski, J., Fukuda, S. and Salwiński, J. (eds.), New World Situation: New Directions in Concurrent Engineering. London: Springer London, pp. 347-355.

Gurumurthy, A. and Kodali, R. (2012). An application of analytic hierarchy process for the selection of a methodology to improve the product development process. Journal of Modelling in Management, 7(1), pp. 97-121, doi: 10.1108/17465661211208820.

Haque, B. and James-Moore, M. (2004a). Applying Lean Thinking to new product introduction. Journal of Engineering Design, 15(1), pp. 1-31, doi: $10.1080 / 0954482031000150125$.

Haque, B. and James-Moore, M. (2004b). Measures of performance for lean product introduction in the aerospace industry. Proceedings of the Institution of Mechanical Engineers, Part B: Journal of Engineering Manufacture, 218(10), pp. 1387-1398, doi: 10.1243/0954405042323496.

Harland, P.E. and Uddin, Z. (2014). Effects of product platform development: fostering lean product development and production. International Journal of Product Development, 19(5-6), pp. 259-285, doi: 10.1504/IJPD.2014.064881.

Harris, A., Al-Ashaab, A. and Odouza, C. (2006). Knowledge Management to Support Lean Product Development. In Ghodous, P., Dieng-Kuntz, R. and Loureiro, G. (eds.), Leading the Web in Concurrent Engineering: Next Generation Concurrent Engineering. Amsterdam: IOS Press, pp. 304-316.

Helander, M., Bergqvist, R., Stetler, K.L. and Magnusson, M. (2015). Applying lean in product development - enabler or inhibitor of creativity? International Journal of Technology Management, 68(1-2), pp. 49-69, doi: 10.1504/IJTM.2015.068774.

Henke, J.W., Krachenberg, A.R. and Lyons, T.F. (1993). Cross-Functional Teams: Good Concept, Poor Implementation! Journal of Product Innovation Management, 10(3), pp. 216-229, doi: 10.1111/1540-5885.1030216.

Hicks, C. and McGovern, T. (2009). Product life cycle management in engineer-to-order industries. International Journal of Technology Management, 48(2), pp. 153-167, doi: 10.1504/ijtm.2009.024913.

Hille, J. and Eseonu, C. (2015). State-of-the-art review of lean product development practices and their impact on project success. In Long, S., Ng, E.-H. and Squires, A. (eds.), American Society for Engineering Management 2015 International Annual Conference. Indianapolis, IN: ASEM. 
Hinckeldeyn, J., Dekkers, R., Altfeld, N. and Kreutzfeldt, J. (2014). Expanding bottleneck management from manufacturing to product design and engineering processes. Computers \& Industrial Engineering, 76, pp. 415-428, doi: 10.1016/j.cie.2013.08.021.

Hinckeldeyn, J., Dekkers, R. and Kreutzfeldt, J. (2015). Productivity of product design and engineering processes - Unexplored territory for production management techniques? International Journal of Operations \& Production Management, 35(4), pp. 458-486, doi: 10.1108/IJOPM-03-2013-0101.

Hines, P., Francis, M. and Found, P. (2006). Towards lean product lifecycle management: A framework for new product development. Journal of Manufacturing Technology Management, 17(7), pp. 866-887, doi: 10.1108/17410380610688214.

Hines, P., Holweg, M. and Rich, N. (2004). Learning to evolve: A review of contemporary lean thinking. International Journal of Operations \& Production Management, 24(10), pp. 994-1011, doi: 10.1108/01443570410558049.

Hodgson, G. M. (1993). Economics and Evolution - Bringing Life Back into Economics. Cambridge: Polity Press.

Hoe, S.L. (2007). Organisational Learning: Conceptual Links to Individual Learning, Learning Organisation and Knowledge Management. Journal of Information \& Knowledge Management, 6(3), pp. 211-217, doi: 10.1142/S0219649207001779.

Hölttä, V., Mahlamäki, K., Eisto, T. and Ström, M. (2010). Lean Information Management Model for Engineering Changes. World Academy of Science, Engineering and Technology, 42, pp. 1459-1466, doi: 10.1.1.294.809.

Hopewell, S., McDonald, S., Clarke, M.J. and Egger, M. (2007). Grey literature in metaanalyses of randomized trials of health care interventions. Cochrane Database of Systematic Reviews, (2), doi.

Hoppman, J., Rebentisch, E., Dombrowski, U. and Zahn, T. (2009). Efficient Introduction of Lean in Product Development: Results of the Survey. Lean Advancement Initiative/nstitute for Manufacturing and Operations Research. Cambridge, MA: Massachusetts Institue of Technology/Technica University of Braunschweig.

Hoppmann, J., Rebentisch, E., Dombrowski, U. and Zahn, T. (2011). A Framework for Organizing Lean Product Development. Engineering Management Journal, 23(1), pp. 3-15, doi: 10.1080/10429247.2011.11431883.

Ind, N. and Coates, N. (2013). The meanings of co- creation. European Business Review, 25(1), pp. 86-95, doi: 10.1108/09555341311287754.

Institoris, M. and Bligård, L.-O. (2014). Human Factors Engineering as a supportive tool for Lean Product Development. In Laakso, M. and Ekman, K. (eds.), NordDesign. Espoo.

Johansson, G. and Sundin, E. (2014). Lean and green product development: two sides of the same coin? Journal of Cleaner Production, 85, pp. 104-121, doi: 10.1016/j.jclepro.2014.04.005.

Joore, P. and Brezet, H. (2015). A Multilevel Design Model: the mutual relationship between product-service system development and societal change processes. Journal of Cleaner Production, 97(Special Volume), pp. 92-105, doi: 10.1016/j.jclepro.2014.06.043.

Jørgensen, B., \& Emmitt, S. (2008). Lost in transition: the transfer of lean manufacturing to construction. Engineering, Construction and Architectural Management, 15(4), pp. 383-398. doi: 10.1108/09699980810886874

Kamath, R.R. and Liker, J.K. (1994). A Second Look at Japanese Product Development. Harvard Business Review, 74(6), pp. 154-170. 
Karabag, S.F. and Berggren, C. (2016). Misconduct, Marginality and Editorial Practices in Management, Business and Economics Journals. PLoS ONE, 11(7), pp. e0159492/0159491-0159425, doi: 10.1371/journal.pone.0159492.

Karademir, Ş. and Cangelir, C. (2013). Lean Approach in Concurrent Engineering Applications. In Bil, C., Mo, J. and Stjepandić, J. (eds.), 20th ISPE International Conference on Concurrent Engineering. Melbourne: IOS Press.

Karlsson, C. and Åhlström, P. (1996). The Difficult Path to Lean Product Development. Journal of Product Innovation Management, 13(4), pp. 283-295, doi: 10.1111/15405885.1340283.

Karmarkar, U.S. and Kubat, P. (1987). Modular product design and product support. European Journal of Operational Research, 29(1), pp. 74-82, doi: 10.1016/03772217(87)90195-0.

Kerga, E., Rosso, A., Bessega, W., Bianchi, A., Moretti, C. and Terzi, S. (2013). Compact teams: A model to achieve lean in product development. International Conference on Engineering, Technology and Innovation \& IEEE International Technology Management Conference. the Hague.

Khan, M., Al-Ashaab, A., Doultsinou, A., Shehab, E., Ewers, P. and Sulowski, R. (2011). Set-Based Concurrent Engineering process within the LeanPPD environment. In Frey, D.D., Fukuda, S. and Rock, G. (eds.), Improving Complex Systems Today: Proceedings of the 18th ISPE International Conference on Concurrent Engineering. London: Springer London, pp. 433-440.

Khan, M.S. (2012). The construction of a model for lean product development. School of Applied Sciences. Cranfield: Cranfield University.

Khan, M.S., Al-Ashaab, A., Shehab, E., Haque, B., Ewers, P., Sorli, M. and Sopelana, A. (2013). Towards lean product and process development. International Journal of Computer Integrated Manufacturing, 26(12), pp. 1105-1116, doi: 10.1080/0951192X.2011.608723.

King, R. (1987). Listening to the Voice of the Customer: Using the Quality Function Deployment System. National Productivity Review, 6(3), pp. 277-281, doi: 10.1002/npr.4040060312.

Kirner, K.G.M., Siyam, G.I., Lindemann, U., Wynn, D.C. and Clarkson, P.J. (2013). Information in Lean Product Development: Assessment of Value and Waste. In Chakrabarti, A. and Prakash, V.R. (eds.), 4th International Conference on Research into Design: Global Product Development. India: Springer India, pp. 809-819.

Koufteros, X., Vonderembse, M. and Doll, W. (2001). Concurrent Engineering and its Consequences. Journal of Operations Management, 19(1), pp. 97-115, doi.

Krishnan, V., Eppinger, S.D. and Whitney, D.E. (1997). A Model-Based Framework to Overlap Product Development Activities. Management Science, 43(4), pp. 437-451, doi: $10.1287 / \mathrm{mnsc} .43 .4 .437$.

Kusiak, A. and Park, K. (1990). Concurrent engineering: decomposition and scheduling of design activities. International Journal of Production Research, 28(10), pp. 1883-1900, doi: $10.1080 / 00207549008942841$.

Lee, M.-C. and Chang, T. (2010). Developing a lean design for Six Sigma through supply chain methodology. International Journal of Productivity and Quality Management, 6(4), pp. 407-434, doi: 10.1504/IJPQM.2010.035891. 
León, H.C.M. and Farris, J.A. (2011). Lean Product Development Research: Current State and Future Directions. Engineering Management Journal, 23(1), pp. 29-51, doi: 10.1080/10429247.2011.11431885.

Letens, G., Farris, J.A. and Van Aken, E.M. (2011). A Multilevel Framework for Lean Product Development System Design. Engineering Management Journal, 23(1), pp. 69-85, doi: 10.1080/10429247.2011.11431887.

Liker, J.K. and Morgan, J. (2011). Lean Product Development as a System: A Case Study of Body and Stamping Development at Ford. Engineering Management Journal, 23(1), pp. 16-28, doi: 10.1080/10429247.2011.11431884.

Liker, J.K. and Morgan, J.M. (2006). The Toyota Way in Services: The Case of Lean Product Development. Academy of Management Perspectives, 20(2), pp. 5-20, doi: 10.5465/AMP.2006.20591002.

Lindlöf, L. and Söderberg, B. (2011). Pros and cons of lean visual planning: experiences from four product development organisations. International Journal of Technology Intelligence and Planning, 7(3), pp. 269-279, doi: 10.1504/IJTIP.2011.044614.

Lindlöf, L., Söderberg, B. and Persson, M. (2013). Practices supporting knowledge transfer an analysis of lean product development. International Journal of Computer Integrated Manufacturing, 26(12), pp. 1128-1135, doi: 10.1080/0951192X.2011.651160.

MacCormack, A., Crandall, W., Henderson, P. and Toft, P. (2012). Do You Need a New Product-Development Strategy? Research-Technology Management, 55(1), pp. 34-43, doi: 10.5437/08956308X5501014.

MacDonald, S. and Kam, J. (2007). Ring a Ring o' Roses: Quality Journals and Gamesmanship in Management Studies. Journal of Management Studies, 44(4), pp. 640-655, doi: 10.1111/j.1467-6486.2007.00704.x.

Mahlamäki, K., Ström, M., Eisto, T. and Höllta, V. (2009). Lean product development point of view to current challenges of engineering change management in traditional manufacturing industries. IEEE International Technology Management Conference. Leiden: IEEE.

Maksimovic, M. (2013). Lean knowledge life cycle framework to support lean product development. Cranfield: Cranfield University.

Maritan, D. (2015). Quality Function Deployment (QFD): Definitions, History and Models. Practical Manual of Quality Function Deployment. Cham: Springer International Publishing, pp. 1-32.

Mayrl, P., McManus, H.L. and Boutellier, R. (2013). Eliciting product development knowledge using value stream mapping. International Journal of Product Development, 18(6), pp. 492-511, doi: 10.1504/IJPD.2013.058548.

McManus, H.L., Haggerty, A. and Murman, E. (2007). Lean engineering: a framework for doing the right thing right. The Aeronautical Journal, 111(1116), pp. 105-114, doi.

McNeel, R. and Kren, L. (2004). How Lean-manufacturing principles speed product design. Machine Design, 76(7), pp. 122, doi.

Meerkamm, H. (1994). Design for X-A Core Area of Design Methodology. Journal of Engineering Design, 5(2), pp. 165-181, doi: 10.1080/09544829408907881.

Meybodi, M.Z. (2013). The links between lean manufacturing practices and concurrent engineering method of new product development: An empirical study. Benchmarking: An International Journal, 20(3), pp. 362-376, doi: 10.1108/14635771311318135.

Meyer, M.H. and Utterback, J.M. (1993). The Product Family and the Dynamics of Core Capability. Sloan Management Review, 34(3), pp. 29-47, doi. 
Micklethwait, J. and Wooldridge, A. (1996). The Witch Doctors - What the Management Gurus are Saying, Why it Matters and How to Make Sense of it London: Heinemann.

Miles, B. (1990). Design for Manufacture Techniques Help the Team Make Early Decisions. Journal of Engineering Design, 1(4), pp. 365-371, doi: 10.1080/09544829008901664.

Morgan, J.M. (2002). High performance product development: A systems approach to a lean product development process. Industrial and Operations Engineering. Ann Arbor, MI: University of Michigan.

Mund, K., Pieterse, K. and Cameron, S. (2015). Lean product engineering in the South African automotive industry. Journal of Manufacturing Technology Management, 26(5), pp. 703-724, doi: 10.1108/JMTM-05-2013-0062.

Murman, E.M. (2008). Lean Aerospace Engineering. ESD Working Papers. Boston, MA: Massachusetts Institute of Technology. Engineering Systems Division.

Mynott, C. (2012). Lean Product Development - A Manager's Guide Stevenage: The Institution of Engineering and Technology.

Negroni, D.Y. and Trabasso, L.G. (2009). A Quality Improving Method to Assist the Integrated Product Development Process. In Norell Bergendahl, M., Grimheden, M., Leifer, L., Skogstad, P. and Lindemann, U. (eds.), 17th International Conference on Engineering Design. Palo Alto, CA.

Nepal, B.P., Yadav, O.P. and Solanki, R. (2011). Improving the NPD Process by Applying Lean Principles: A Case Study. Engineering Management Journal, 23(1), pp. 52-68, doi: 10.1080/10429247.2011.11431886.

Oehmen, J. and Rebentisch, E. (2010a). Risk Management in Lean Product Development. LAI Paper Series "Lean Product Development for Practitioners". Cambridge, MA: Massachusetts Institute of Technology.

Oehmen, J. and Rebentisch, E. (2010b). Waste in Lean Product Development. LAI Paper Series "Lean Product Development for Practitioners". Cambridge, MA: Massachusetts Institute of Technology.

Ohno, T. (1988). Toyota Production System: Beyond Large-Scale Production New York: Productivity Press.

Oppenheim, B.W. (2004). Lean Product Development Flow. Systems Engineering, 7(4), pp. 352-376, doi: 10.1002/sys.20014.

Oppenheim, B.W., Murman, E.M. and Secor, D.A. (2011). Lean Enablers for Systems Engineering. Systems Engineering, 14(1), pp. 29-55, doi: 10.1002/sys.20161.

Page, A.L. (1993). Assessing new product development practices and performance: Establishing crucial norms. Journal of Product Innovation Management, 10(4), pp. 273-290, doi: 10.1016/0737-6782(93)90071-W.

Pahl, G., Beitz, W., Feldhusen, J. and Grote, K.-H. (2007). Engineering Design: A Systematic Approach London: Springer Verlag.

Paulk, M.C. (1993). Comparing ISO 9001 and the Capability Maturity Model for Software. Software Quality Journal, 2(4), pp. 245-256, doi: 10.1007/bf00403767.

Paulk, M.C., Curtis, B., Chrissis, M.B. and Weber, C.V. (1993). Capability maturity model, version 1.1. IEEE Software, 10(4), pp. 18-27, doi: 10.1109/52.219617.

Pavnaskar, S.J. and Gershenson, J.K. (2005). A Systematic Method for Leaning Engineering Processes. Design for Manufacturing and the Life Cycle Conference. Long Beach, CA: ASME. 
Pernstål, J., Feldt, R. and Gorschek, T. (2013). The lean gap: A review of lean approaches to large-scale software systems development. Journal of Systems and Software, 86(11), pp. 2797-2821, doi: 10.1016/j.jss.2013.06.035.

Pessôa, M.V.P., Loureiro, G. and Alves, J.M. (2007). An approach to lean product development planning. In Loureiro, G. and Curran, R. (eds.), Complex Systems Concurrent Engineering: Collaboration, Technology Innovation and Sustainability. London: Springer London, pp. 229-237.

Petersen, K., Wohlin, C. and Baca, D. (2009). The Waterfall Model in Large-Scale Development. In Bomarius, F., Oivo, M., Jaring, P. and Abrahamsson, P. (eds.), Product-Focused Software Process Improvement. Berlin, Heidelberg: Springer Berlin Heidelberg, pp. 386-400.

Pinto, M.B. and Pinto, J.K. (1990). Project Team Communication and Cross-Functional Cooperation in New Program Development. Journal of Product Innovation Management, 7(3 ), pp. 200-212, doi: 10.1111/1540-5885.730200.

PMI (Project Management Institute) (1996). Guide to the Project Management Body of Knowledge. Sylva, NC: PMI Standards Committee.

Powell, D., Strandhagen, J.O., Tommelein, I., Ballard, G. and Rossi, M. (2014). A New Set of Principles for Pursuing the Lean Ideal in Engineer-to-order Manufacturers. Procedia CIRP, 17, pp. 571-576, doi: 10.1016/j.procir.2014.01.137.

Pugh, S. (1981). Concept selection: a method that works. In Hubka, V. (ed.), International Conference on Engineering Design. Rome.

Pugh, S. (1991). Total Design Reading, MA: Addison-Wesley.

Qudrat-Ullah, H., Seong, B.S. and Mills, B.L. (2012). Improving high variable-low volume operations: an exploration into the lean product development. International Journal of Technology Management, 57(1/2/3), pp. 49-70, doi: 10.1504/IJTM.2012.043951.

Radeka, K. and Sutton, T. (2007). What is "lean" about product development? PMDA Visions, 31(2), pp. 11-15, doi.

Radhakrishan, R. and McAdams, D.A. (2005). A methodology for model selection in engineering design. Journal of Mechanical Design, 127(3), pp. 378-387, doi: 10.1115/1.1830048.

Rauch, E., Dallasega, P. and Matt, D.T. (2015). Axiomatic Design Based Guidelines for the Design of a Lean Product Development Process. Procedia CIRP, 34, pp. 112-118, doi: 10.1016/j.procir.2015.07.005.

Raudberget, D. (2010). Practical Applications of Set-Based Concurrent Engineering in Industry. Strojniški vestnik - Journal of Mechanical Engineering, 56, pp. 685-695, doi.

Rauhut, M. (2011). Synchronisation von Entwicklungsprozessen durch Taktung. Aachen: RWTH.

Rebentisch, E. (2005). Lean Product Development. Integrating the Lean Enterprise. Boston, MA: Massachusetts Institute of Technology.

Reinertsen, D. (2005). Let it flow: how lean product development sparked a revolution. Industrial Engineer.

Reinertsen, D. and Shaeffer, L. (2005). Making R\&D Lean. Research Technology Management, 48(4), pp. 51-57, doi.

Ringen, G. and Holtskog, H. (2013). How enablers for lean product development motivate engineers. International Journal of Computer Integrated Manufacturing, 26(12), pp. 1117-1127, doi: 10.1080/0951192X.2011.593046. 
Ringen, G. and Lodgaard, E. (2009). Lean Product Development in the Automotive Supplier Industry. SAE World Congress \& Exhibition. Detroit, MI: SAE International.

Ringen, G. and Welo, T. (2015). Knowledge Based Development Practices in Systems Engineering Companies: A Comparative Study. 9th Annual IEEE International Systems Conference Vancouver, BC: IEEE.

Rossi, M., Kerga, E., Taisch, M. and Terzi, S. (2012). Learning Methodologies to Diffuse Lean Product Development to Industries. In Rivest, L., Bouras, A. and Louhichi, B. (eds.), Product Lifecycle Management. Towards Knowledge-Rich Enterprises: IFIP WG 5.1 International Conference, PLM 2012, Montreal, QC, Canada, July 9-11, 2012, Revised Selected Papers. Berlin, Heidelberg: Springer Berlin Heidelberg, pp. 287-298.

Rossi, M., Taisch, M. and Terzi, S. (2012). Lean product development: A five-steps methodology for continuous improvement. In Katzy, B., Holzmann, T., Sailer, K. and Thoben, K.-D. (eds.), 18th International Conference on Engineering, Technology and Innovation. Munich: IEEE.

Royce, W.W. (1970). Managing the Development of Large Software Systems. Technical Papers of Western Electronic Show and Convention. Los Angeles, CA.

Rozenfeld, H., Forcellini, F.A., Amamral, D.C., de Toledo, J.C., da Silva, S.L., Alliprandini, D.H. and Scalice, R.K. (2006). Gestão de desenvolvimento de produtos: uma referência para a melhoria do processo São Paulo: Editora Saraiva.

Ryan, J.E. and Reik, M.P. (2010). Applying the Core Elements of a Lean Enterprise to Product Development. In Pokojski, J., Fukuda, S. and Salwiński, J. (eds.), New World Situation: New Directions in Concurrent Engineering: Proceedings of the 17th ISPE International Conference on Concurrent Engineering. London: Springer London, pp. 367-375.

Saad, N.M., Al-Ashaab, A., Shehab, E. and Maksimovic, M. (2013). A3 Thinking Approach to Support Problem Solving in Lean Product and Process Development. In Stjepandić, J., Rock, G. and Bil, C. (eds.), Concurrent Engineering Approaches for Sustainable Product Development in a Multi-Disciplinary Environment: Proceedings of the 19th ISPE International Conference on Concurrent Engineering. London: Springer London, pp. 871-882.

Sackett, P.J. and Holbrook, A.E.K. (1988). DFA as a primary process decreases design deficiencies. Assembly Automation, 8(3), pp. 137-140, doi.

Salgado, E.G., Mello, C.H.P., Leal, F. and da Silva, C.E.S. (2014). Waste investigation on product development process using the lean and simulation approaches. Product: Management \& Development, 12(1), pp. 3-13, doi: 10.4322/pmd.2014.001.

Salgado, E.G., Mello, C.H.P., Leal, F. and da Silva, C.E.S. (2015). Investigating waste on new product development: case study. Product: Management \& Development, 13(1), pp. 31-37, doi: 10.4322/pmd.2015.004.

Salgado, E.G., Salomon, V.A.P. and Mello, C.H.P. (2012). Analytic hierarchy prioritisation of new product development activities for electronics manufacturing. International Journal of Production Research, 50(17), pp. 4860-4866, doi: 10.1080/00207543.2012.657972.

Sánchez, A.M. and Pérez, M.P. (2001). Lean indicators and manufacturing strategies. International Journal of Operations \& Production Management, 21(11), pp. 14331452, doi: 10.1108/01443570110407436.

Sanchez, R. (2004). Creating Modular Platforms for Strategic Flexibility. Design Management Review, 15(1), pp. 58-67, doi. 
Saunders, T., Gao, J. and Shah, S. (2014). A case study to evaluate lean product development practices in the global automotive industry. International Journal of Product Development, 19(5-6), pp. 307-327, doi: 10.1504/IJPD.2014.064882.

Schuh, G., Korthals, K., Rudolf, S. and Breunig, S. (2014). Systematic waste elimination in lean product development using generic activities. International Journal of Product Development, 19(5-6), pp. 388-412, doi: 10.1504/IJPD.2014.064886.

Schuh, G., Lenders, M. and Hieber, S. (2008). Lean Innovation: Introducing Value Systems to Product Development. Portland International Conference on Management of Engineering \& Technology. Cape Town: IEEE.

Schulze, A. and Störmer, T. (2012). Lean product development - enabling management factors for waste elimination. International Journal of Technology Management, 57(1/2/3), pp. 71-91, doi: 10.1504/IJTM.2012.043952.

Shamsuzzoha, A. and Kekale, T. (2010). Platform-oriented product development: prospects and limitations. International Journal of Business Innovation and Research, 4(3), pp. 179-194, doi.

Shen, X.X., Tan, K.C. and Xie, M. (2000). An integrated approach to innovative product development using Kano's model and QFD. European Journal of Innovation Management, 3(2), pp. 91-99, doi: 10.1108/14601060010298435.

Shigley, J.E. and Mischke, C.R. (1989). Mechanical Engineering Design New York: McGraw-Hill.

Shillito, M.L. and De Marle, D.J. (1992). Value: Its Measurement, Design, and Management New York: John Wiley \& Sons.

Shingo, S. (1996). A Study of the Toyota Production System from an Industrial Engineering Viewpoint New York, NY: Productivity Press.

Singer, D.J., Doerry, N. and Buckley, M.E. (2009). What Is Set-Based Design? Naval Engineers Journal, 121(4), pp. 31-43, doi: 10.1111/j.1559-3584.2009.00226.x.

Sivasubramaniam, N., Liebowitz, S.J. and Lackman, C.L. (2012). Determinants of New Product Development Team Performance: A Meta-analytic Review. Journal of Product Innovation Management, 29(5), pp. 803-820, doi: 10.1111/j.1540-5885.2012.00940.x.

Siyam, G.I., Kirner, K., Wynn, D.C., Lindemann, U. and Clarkson, P.J. (2013). Lean product development in practice: Insights from 4 companies. In Lindemann, U., Srinivasan, V., Kim, Y.S., Lee, S.W., Clarkson, J. and Cascini, G. (eds.), 19th International Conference on Engineering Design. Seoul: Design Society.

Siyam, G.I., Wynn, D.C. and Clarkson, P.J. (2015). Review of Value and Lean in Complex Product Development. Systems Engineering, 18(2), pp. 192-207, doi: 10.1002/sys.21299.

Sobek II, D.K., Liker, J.K. and Ward, A.C. (1998). Another Look at How Toyota Integrates Product Development. Harvard Business Review, 76(4), pp. 36-47, doi.

Sopelana, A., Flores, M., Martinez, L., Flores, K. and Sorli, M. (2012). The Application of an Assessment Tool for Lean Product Development: An exploratory study in Spanish Companies. In Katzy, B., Holzmann, T., Sailer, K. and Thoben, K.-D. (eds.), 18th International Conference on Engineering, Technology and Innovation. Munich: IEEE.

Sorli, M., Maksimovic, M., Al-Ashaab, A., Sulowski, R., Shehab, E. and Sopelana, A. (2012). Development of KBE system to support LeanPPD application. In Katzy, B., Holzmann, T., Sailer, K. and Thoben, K.-D. (eds.), 18th International Conference on Engineering, Technology and Innovation. Munich: IEEE. 
Sorli, M., Sopelana, A., Salgado, M., Pelaez, G. and Ares, E. (2011). Expanding Lean Thinking to the Product and Process Design and Development within the Framework of Sustainability. In Marcos, M. and Salguero, J. (eds.), 4th Manufacturing Engineering Society International Conference. Cadiz: AIP Conference Proceedings.

Sorli, M., Sopelana, A., Taisch, M., Al-Shaab, A., Keast, J., Flores, M., Skotic, D. and Martinez, L. (2010). Applying lean thinking concepts to new product development. International Conference on Advances in Production Management Systems. Cernobbio, Lake Como.

Stenholm, D., Mathiesen, H. and Bergsjo, D. (2015). Knowledge Based Development in Automotive Industry Guided by Lean Enablers for System Engineering. Procedia Computer Science, 44, pp. 244-253, doi: 10.1016/j.procs.2015.03.047.

Stevens, G.A. and Burley, J. (1997). 3,000 Raw Ideas = 1 Commercial Success! ResearchTechnology Management, 40(3), pp. 16-27, doi.

Stockton, D.J. (1983). Improving the new product development process. School of Mechanical, Electrical and Manufacturing Engineering. Loughborough: Loughboroug University of Technology.

Ström, M., Alemyr, M., Bükk, S., Gustafsson, G. and Johannesson, H. (2012). Transformation to lean product development - Approaches at two automotive suppliers. In Marjanović, D., Štorga, M., Pavković, N. and Bojčetić, N. (eds.), 12th International Design Conference. Dubrovnik: Design Society.

Subramoniam, R., Abusamra, G. and Hostetler, D. (2009). Lean Engineering Implementation Challenges for Automotive Remanufacturing. SAE World Congress \& Exhibition. Detroit, MI: SAE International.

Suh, N.P. (1990). The Principles of Design New York: Oxford University Press.

Sutton, R.I. and Staw, B.M. (1995). What Theory is Not. Administrative Science Quarterly, 40(3), pp. 371-384, doi: 10.2307/2393788.

Swan, H. and Furuhjelm, J. (2010). Creating Value Through Lean Product Development Towards a Generic Framework. In Dagman, A. and Söderberg, R. (eds.), 8th International NordDesign Conference. Göteborg.

Tähemaa, T., Temerbulatova, A. and Karjust, K. (2012). Lean Product Development in Estonian SMEs. In Otto, T. (ed.), 8th International Conference of DAAAM Baltic Industrial Engineering. Tallinn: DAAAM Baltic.

Takeuchi, H. and Nonaka, I. (1986). The new new product development game. Harvard Business Review, 64(1), pp. 137-146, doi.

Tortorella, G.L., de Castro Fettermann, D., Marodin, G.A. and Fogliatto, F.S. (2015). Lean Product Development (LPD) Enablers for Product Development Process Improvement. In Davim, P.J. (ed.), Research Advances in Industrial Engineering. Cham: Springer International Publishing, pp. 31-57.

Tranfield, D., Denyer, D. and Smart, P. (2003). Towards a Methodology for Developing Evidence-Informed Management Knowledge by Means of Systematic Review. British Journal of Management, 14(3), pp. 207-222, doi: 10.1111/1467-8551.00375.

Trim, P. and Pan, H. (2005). A new product launch strategy (NPLS) model for pharmaceutical companies. European Business Review, 17(4), pp. 325-339, doi: 10.1108/09555340510607370.

Trimi, S. and Berbegal-Mirabent, J. (2012). Business model innovation in entrepreneurship. International Entrepreneurship and Management Journal, 8(4), pp. 449-465, doi: 10.1007/s11365-012-0234-3. 
Tyagi, S., Choudhary, A., Cai, X. and Yang, K. (2015). Value stream mapping to reduce the lead-time of a product development process. International Journal of Production Economics, 160, pp. 202-212, doi: 10.1016/j.ijpe.2014.11.002.

Ullman, D.G. (2009). The Mechanical Design Process New York: McGraw-Hill.

Ulrich, K. and Eppinger, S. (1995). Product Design and Development New York: McGrawHill.

Ulrich, K. and Eppinger, S. (2000). Product Design and Development New York: McGrawHill.

Ulrich, K. and Eppinger, S. (2004). Product Design and Development New York: McGrawHill.

Ulrich, K. and Eppinger, S. (2007). Product Design and Development New York: McGrawHill.

Ulrich, K. and Eppinger, S. (2008). Product Design and Development New York: McGrawHill.

Vardouli, T. (2015). Who Designs? In Bihanic, D. (ed.), Empowering Users through Design: Interdisciplinary Studies and Combined Approaches for Technological Products and Services. Cham: Springer International Publishing, pp. 13-41.

Veldman, J. and Klingenberg, W. (2009). Applicability of the capability maturity model for engineer-to-order firms. International Journal of Technology Management, 48(2), pp. 219-239, doi: 10.1504/IJTM.2009.024917.

von Würtemberg, L.M., Lilliesk, J. and Ericsson, E. (2011). Abstract model of LPD: A critical review of the Lean Product Development concept. Portland International Center for Management of Engineering and Technology Conference. Portland, OR.

Vosgien, T., Jankovic, M., Eynard, B., Nguyen Van, T. and Bocquet, J.-C. (2011). Lean approach to integrate collaborative product development processes and digital engineering systems. In Culley, S.J., Hicks, B.J., Mcaloone, T.C., Howard, T.J. and Clarkson, P.J. (eds.), 18th International Conference on Engineering Design. Lyngby.

Walton, M. (1999). Strategies for Lean Product Development. Working Paper Series. Cambridge, MA: Center for Technology, Policy, and Industrial Development/Massachusetts Institute of Technology.

Wang, C., Quesada-Pineda, H., Kline, D.E. and Buehlmann, U. (2011). Using value stream mapping to analyze an upholstery furniture engineering process. Forest Products Journal.

Wang, L., Ming, X.G., Kong, F.B., Li, D. and Wang, P.P. (2011). Focus on implementation: a framework for lean product development. Journal of Manufacturing Technology Management, 23(1), pp. 4-24, doi: 10.1108/17410381211196267.

Ward, A., Liker, J.K., Cristiano, J.J. and Sobek II, D.K. (1995). The Second Toyota Paradox: How Delaying Decisions Can Make Better Cars Faster. Sloan Management Review, 36(3), pp. 43-61, doi.

Wasim, A., Shehab, E., Abdalla, H., Al-Ashaab, A., Sulowski, R. and Alam, R. (2013). An innovative cost modelling system to support lean product and process development. The International Journal of Advanced Manufacturing Technology, 65(1), pp. 165-181, doi: 10.1007/s00170-012-4158-4.

Weick, K.E. (1995). What Theory is Not, Theorizing is. Administrative Science Quarterly, 40(3), pp. 385-390, doi: 10.2307/2393789. 
Welo, T. (2011). On the application of lean principles in Product Development: a commentary on models and practices. International Journal of Product Development, 13(4), pp. 316-343, doi: 10.1504/IJPD.2011.042027.

Welo, T., Aschehoug, S.H. and Ringen, G. (2013). Assessing the Relationship between New Product Development Practices and Performance in the Norwegian Manufacturing Industry. In Abramovici, M. and Stark, R. (eds.), Smart Product Engineering (Proceedings of the 23rd CIRP Design Conference, Bochum, Germany, March 11th 13th, 2013). Berlin, Heidelberg: Springer Berlin Heidelberg, pp. 895-904.

Welo, T., Olsen, T.O. and Gudem, M. (2012). Enhancing Product Innovation Through A Customer-Centered, Lean Framework. International Journal of Innovation and Technology Management, 9(6), pp. 1250041/1250041-1250028, doi: 10.1142/S0219877012500411.

Welo, T. and Ringen, G. (2015). Investigating Lean Development Practices in SE Companies: A Comparative Study Between Sectors. Procedia Computer Science, 44, pp. 234-243, doi: 10.1016/j.procs.2015.03.056.

Wheelwright, S.C. and Clark., K.B. (1992). Revolutionizing Product Development New York: Free Press.

Wohlin, C. and Prikladnicki, R. (2013). Systematic literature reviews in software engineering. Information and Software Technology, 55(6), pp. 919-920, doi: 10.1016/j.infsof.2013.02.002.

Wohnhas, S. (2014). Value Management in Lean Product Development. SAVE International Annual Conference. Chicago, IL: SAVE International.

Womack, J.P. and Jones, D.T. (1996). Lean Thinking New York: Simon \& Schuster.

Womack, J.P., Jones, D.T. and Roos, D. (1991). The Machine That Changed the World: The Story of Lean Production New York: Free Press.

Wu, B. (1994). Manufacturing Systems Design and Analysis: Context and Techniques London: Chapman \& Hall.

Yang, C.-C. (2005). The refined Kano's model and its application. Total Quality Management \& Business Excellence, 16(10), pp. 1127-1137, doi: 10.1080/14783360500235850.

Yang, K. and Cai, X. (2009). The integration of DFSS, lean product development and lean knowledge management. International Journal of Six Sigma and Competitive Advantage, 5(1), pp. 75-99, doi: 10.1504/IJSSCA.2009.024216. 


\section{Appendix}

These are retrieved references for the review that have not been mentioned in the main body

of text and the tables:

Al-Ashaab, A., Petritsch, C., Gourdin, M., Aliende, U.A., Andino, A., Varro, B., Rigatti, C., Golob, M., Summers, M., El-Nounu, A. and Kayani, A. (2013). Lean Product Development Performance Measurement Tool. 11th International Conference on Manufacturing Research. Cranfield.

Al-Ashaab, A., Shehab, E., Alam, R., Sopelana, A., Sorli, M., Flores, M., Taisch, M., Stokic, D. and James-Moore, M. (2010). The Conceptual LeanPPD Model. In Pokojski, J., Fukuda, S. and Salwiński, J. (eds.), New World Situation: New Directions in Concurrent Engineering (Proceedings of the 17th ISPE International Conference on Concurrent Engineering). London: Springer London, pp. 339-346.

Al-Ashaab, A., Flores, M., Khan, M., Maksimovic, M., Alam, R., Shebab, E., Doultsinou, A. and Sopelana, A. (2010). The Industrial Requirements of KBE for the LeanPPD Model. APMS Conf. Como.

Anderson, K.M., Grasman, S.E., Ayoub, K., Introne, S. and Smithwick, K. (2011). Using Lean Product Development to Speed Time to Market for Medical Devices. In Doolen, T. and Van Aken, E. (eds.), 20th Annual Industrial Engineering Research Conference. Reno, NV.

Beauregard, Y. (2010). A multi-criteria performance study of lean engineering. Montreal: Concordia University.

Beauregard, Y., Bhuiyan, N. and Thomson, V. (2011). Optimum task size, multitasking and utilization levels for lean product development. In Doolen, T. and Van Aken, E. (eds.), Industrial Engineering Research Conference. Reno, NV.

Beauregard, Y., Bhuiyan, N. and Thomson, V. (2014). Lean engineering performance analysis. International Journal of Product Development, 19(5-6), pp. 366-387, doi: 10.1504/IJPD.2014.064887.

Browning, T.R. (2001). Applying the design structure matrix to system decomposition and integration problems: a review and new directions. IEEE Transactions on Engineering Management, 48(3), pp. 292-306, doi: 10.1109/17.946528.

Cai, T. and Freiheit, T. (2011). Lean Principles in Product Development Processes. In Doolen, T. and Van Aken, E. (eds.), Industrial Engineering Research Conference. Reno, NV.

Cai, T. and Freiheit, T. (2011). Lean Value Creation in the Product Development Process With the Principle of Set Based Concurrent Engineering. 23rd International Conference on Design Theory and Methodology/16th Design for Manufacturing and the Life Cycle Conference. Washington, DC: ASME.

Cai, T. and Freiheit, T. (2014). Resource Allocation for Lean Product Development Using a Value Creation Cell Model. Journal of Mechanical Design, 136(10), pp. 101701/101701-101712, doi: 10.1115/1.4027981.

Candido, G.M. and Kaminski, P.C. (2008). Product value optimisation engineering applied to current component designs: a case study from the Brazilian automotive industry. International Journal of Automotive Technology and Management, 8(3), pp. 270-296, doi: 10.1504/IJATM.2008.020213. 
Correia, A.T., Stokic, D. and Faltus, S. (2014). Mechanisms for communication and knowledge sharing for set-based concurrent engineering. International Journal of Product Development, 19(5-6), pp. 328-347, doi: 10.1504/IJPD.2014.064883.

De Paula, I.C., Fogliatto, F.S. and Cristofari, C.A. (2012). Method for assessing the maturity of product development management: A proposal. African Journal of Business Management, 6(38), pp. 10285-10302, doi: 10.5897/AJBM10.1553.

Dombrowski, U., Zahn, T. and Schulze, S. (2011). State of the Art-Lean Development. In Thompson, M.K. (ed.), 21st CIRP Design Conference. Daejeon: Korea Advanced Institute of Science and Technology.

Farahani, E.V. and Buiyan, N. (2013). Study of flow in Lean Product Development. Institute of Industrial Engineers Annual Conference. San Juan, Puerto Rico: Institute of Industrial Engineers.

Garcia, P. and Drogosz, J. (2007). Lean Engineering - Best Practice in the Automotive Industry. SAE Technical Paper.

Gautam, N. (2005). A design reuse based framework for lean product development Ann Arbor, MI: Wayne State University.

Gudem, M., Steiniert, M. and Welo, T. (2014). From Lean Product Development to Lean Innovation: Searching for a More Valid Approach for Promoting Utilitarian and Emotional Value. International Journal of Innovation and Technology Management, 11(2), pp. 1450008/1450001-1450020, doi: 10.1142/S0219877014500084.

Hafer, M. (2011). Applying lean to new product development. Manufacturing Engineering, 147(5), pp. 85-91, doi.

Haggerty, A. and Murman, E. (2006). Evidence of lean engineering in aircraft programs. 25th International Congress of the Aeronautical Sciences. Hamburg.

Haque, B. (2003). Lean engineering in the aerospace industry. Proceedings of the Institution of Mechanical Engineers, Part B: Journal of Engineering Manufacture, 217(10), pp. 1409-1420, doi: 10.1243/095440503322617180.

Haque, B. and James-Moore, M. (2002). Characteristics of lean product introduction. International Journal of Automotive Technology and Management, 2(3-4), pp. 378401, doi: 10.1504/IJATM.2002.002096.

Hines, P. and Packham, J. (2008). Implementing Lean New Product Development. In Fowler, J. and Mason, S. (eds.), Industrial Engineering Research Conference. Vancouver, BC: Institute of industrial Engineers.

Jasti, V.N.K. and Kodali, R. (2014). Validity and reliability of lean product development frameworks in Indian manufacturing industry. Measuring Business Excellence, 18(4), pp. 27-53, doi: 10.1108/MBE-12-2013-0062.

Khan, M.S., Al-Ashaab, A., Shehab, E., Kerga, E., Martin, C. and Ewers, P. (2015). Define value: applying the first lean principle to product development. International Journal of Industrial and Systems Engineering, 21(1), pp. 1-30, doi: 10.1504/IJISE.2015.070868.

Lemieux, A.-A., Pellerin, R. and Lamouri, S. (2013). A Mixed Performance and Adoption Alignment Framework for Guiding Leanness and Agility Improvement Initiatives in Product Development. Journal of Enterprise Transformation, 3(3), pp. 161-186, doi: 10.1080/19488289.2013.818597.

Lempia, D. (2008). Using Lean principles and MBE in design and development of avionics equipment at Rockwell Collins. In Grant, I. (ed.), 26th Congress Int Council of the Aeronautical Sciences. Anchorage, AK. 
Letens, G., Van Aken, E.M., Farris, J.A. and Martínez, C. (2009). Optimizing stakeholder value and reducing waste in new product development projects. 3oth Annual National Conference of the American Society for Engineering Management Springfield, MO: ASEM.

Machado, M.A. (2013). New Product Development: From Efficiency to Value Creation. PICMET. San Jose, CA.

Maginness, M., Shehab, E. and Beadle, C. (2011). Value Stream Analysis of Manufacturing Engineering New Product Introduction Processes. In Frey, D.D., Fukuda, S. and Rock, G. (eds.), Improving Complex Systems Today: Proceedings of the 18th ISPE International Conference on Concurrent Engineering. London: Springer London, pp. 327-334.

Maginness, M., Shehab, E. and Beadle, C. (2011). Planning Manufacturing in a Concurrent Engineering Environment: A Case Study. In Frey, D.D., Fukuda, S. and Rock, G. (eds.), Improving Complex Systems Today: Proceedings of the 18th ISPE International Conference on Concurrent Engineering. London: Springer London, pp. 417-424.

Maginness, M., Shehab, E., Beadle, C. and Carswell, M. (2013). Principles for aerospace Manufacturing Engineering in integrated New Product Introduction. Proceedings of the Institution of Mechanical Engineers, Part B: Journal of Engineering Manufacture, doi: 10.1177/0954405413512811.

McManus, H. and Millard, R. (2002). Value Stream Analysis and Mapping for Product Development. International Council of the Aeronautical Sciences. Toronto.

Morgan, J.M. and Liker, J.K. (2006). The Toyota Product Development System: Integrating People, Process and Technology New York, NY: Productivity Press.

Murman, E.M. (2012). Innovation in aeronautics through Lean Engineering. In Young, T.M. and Hirst, M. (eds.), Innovation in aeronautics. Oxford: Woodhead Publishing, pp. $323-360$.

Murman, E. (2003). Lean Systems Engineering II. Boston, MA.

Nepal, B.P., Monplaisir, L., Hammond, R., Wrobel, M., D'hondt, A. and Herr, G. (2007). Lean Product Development: An Approach to Achieve Ford's Global Product Development System Milestones. American Society for Engineering Management National Conference. Chattanooga, TN: ASME.

Nightingale, D. (2002). Lean Engineering Product Development. Massachusetts Institute of Technology. Boston, MA.

Oehmen, J. (2012). Lean Enablers for Managing Engineering Programs. NDIA Program Management Systems Committee.

Oppenheim, B.W. (2011). Lean for Systems Engineering with Lean Enablers for Systems Engineering Hoboken, NJ: John Wiley \& Sons.

Parry, G., Graves, A. and James-Moore, M. (2008). Lean New Product Introduction: a UK Aerospace Perspective. Bath: University of Bath.

Parsons, M.J. and Josefik, N.M. (2009). Accelerating Production Readiness Using Lean Product Development. 7th International Fuel Cell Science, Engineering and Technology Conference. Newport Beach, CA: ASME.

Paschkewitz, J.J. (2014). Risk Management in Lean Product Development. Reliability and Maintainability Symposium. Colorado Springs, CO: IEEE.

Pavnaskar, S.J. and Gershenson, J.K. (2004). The Application of Value Stream Mapping to Lean Engineering. 8th Design for Manufacturing Conference. Salt Lake City, UT: ASME. 
Pessôa, M.V.P., Loureiro, G. and Alves, J.M. (2008). A method to lean product development planning. Product: Management \& Development, 6(2), pp. 143-155, doi.

Pessôa, P.M.V., Seering, W., Rebentisch, E. and Bauch, C. (2009). Understanding the Waste Net: A Method for Waste Elimination Prioritization in Product Development. In Chou, S.-Y., Trappey, A., Pokojski, J. and Smith, S. (eds.), Global Perspective for Competitive Enterprise, Economy and Ecology: Proceedings of the 16th ISPE International Conference on Concurrent Engineering. London: Springer London, pp. 233-242.

Raudberget, D. and Sunnersjö, S. (2010). Experiences of set based concurrent engineering in four product developing companies. In Horváth, I., Mandorli, F. and Rusák, Z. (eds.), 8th International Symposium on Tools and Methods of Competitive Engineering. Ancona.

Raudberget, D.S. (2011). Enabling Set-based Concurrent Engineering in traditional product development. In Culley, S.J., Hicks, B.J., Mcaloone, T.C., Howard, T.J. and Clarkson, P.J. (eds.), 18th International Conference on Engineering Design. Lyngby.

Reinertsen, D. (1999). Lean Thinking Isn't So Simple. Electronic Design, 47(10), pp. 48H.

Rocha, H.M., de Andrade de Souza, C.N. and dos Santos Filho, D.F. (2014). Mass Customization Enablement Through Lean Design \& Set-Based Concurrent Engineering Application. Journal of Operations and Supply Chain Management, 7(2), pp. 124-139, doi: 10.12660/joscmv7n2p124-139.

Rossi, M., Kerga, E.T., Taisch, M. and Terzi, S. (2011). Proposal of a method to systematically identify wastes in New Product Development Process. In Thoben, K.-D., Stich, V. and Imtiaz, A. (eds.), 17th International Conference on Concurrent Enterprising. Aachen: IEEE.

Schulze, A., Schmitt, P., Heinzen, M., Mayrl, P., Heller, D. and Boutellier, R. (2013). Exploring the 4I framework of organisational learning in product development: value stream mapping as a facilitator. International Journal of Computer Integrated Manufacturing, 26(12), pp. 1136-1150, doi: 10.1080/0951192X.2011.608724.

Shirwaiker, R.A. and Okudan, G.E. (2011). Contributions of TRIZ and axiomatic design to leanness in design: an investigation. Procedia Engineering, 9, pp. 730-735, doi: 10.1016/j.proeng.2011.03.162.

Siyam, G.I., Kirner, K., Wynn, D.C., Lindemann, U. and Clarkson, P.J. (2012). Relating value methods to waste types in lean product development. In Marjanović, Dorian, Štorga, M., Pavković, N. and Bojčetić, N. (eds.), 12th International Design Conference. Dubrovnik: Design Science Society.

Siyam, G.I., Kirner, K., Wynn, D.C., Lindemann, U. and Clarkson, P.J. (2012). Value and waste dependencies and guidelines. In Onishi, M., Maurer, M., Kirner, K. and Lindemann, U. (eds.), 14th International Dependency and Structure Modelling Conference. Kyoto.

Sobek II, D.K., Ward, A. and Liker, J.K. (1999). Toyota's Principles of Set-Based Concurrent Engineering. Sloan Management Review, 40(2), pp. 67-83, doi.

Stetler, K.L. (2015). Creativity Just in Time? The Role of Delivery Precision in Product Development. International Journal of Innovation and Technology Management, 12(5), pp. 1550026/1550021-1550017, doi: 10.1142/S0219877015500261.

Taisch, M., Corti, D. and Terzi, S. (2011). Towards a Performance Measurement System for Lean-Oriented NPD Processes. In Bernard, A. (ed.), Global Product Development. Berlin, Heidelberg: Springer Berlin Heidelberg, pp. 653-661. 
Thomas, M. and Singh, N. (2006). Design for Lean Six Sigma (DFLSS): Philosophy, Tools, Potential and Deployment Challenges in Automotive Product Development. Reliability and Robust Design in Automotive Engineering. Detroit, MI: SAE International.

Tingström, J., Gustavsson, H. and Palmér, P. (2010). Implementing Value Stream Mapping VSM in a R\&D organisation. 8th International NordDesign Conference. Göteborg.

Vinodh, S. and Chethan Kumar, A.G. (2015). A Case Study on Lean Product and Process Development. In Davim, P.J. (ed.), Research Advances in Industrial Engineering. Cham: Springer International Publishing, pp. 17-30.

Wangwacharakul, P., Berglund, M., Harlin, U. and Gullander, P. (2014). Cultural Aspects when Implementing Lean Production and Lean Product Development - Experiences from a Swedish Perspective. Quality Innovation Prosperity/Kvalita Inovaća Prosperita, 18(1), pp. 125-140, doi: 10.12776/qip.v18i1.321.

Ward, A.C., Liker, J.K., Sobek II, D.K. and Cristiano, J.J. (1994). Set-based concurrent engineering and Toyota. ASME Design Engineering Technical Conferences. Minneapolis, MN: ASME. 
Table 1: Overview of retrieved publications.

\begin{tabular}{|c|c|c|c|c|}
\hline Keyword & EBSCOhost & Google Scholar & Scopus & Total \\
\hline Lean product development & 14 & 104 & 93 & 141 \\
\hline Lean product and process development & 7 & 38 & 25 & 39 \\
\hline Lean engineering & 10 & 75 & 43 & 83 \\
\hline Subtotal protocol-driven & 16 & 145 & 111 & 189 \\
\hline Snowballing & & & & 17 \\
\hline Serendipitous searching & & & & 1 \\
\hline Total & & & & 207 \\
\hline
\end{tabular}


Table 2: $\quad$ Frequency and combinations of five principles of lean thinking in publications about NPD (n=207).

\begin{tabular}{|c|c|c|c|c|c|}
\hline \multicolumn{5}{|c|}{ Principles of lean thinking } & \multirow[t]{2}{*}{ Frequency } \\
\hline Value & Value stream mapping & Waste & Flow and pull production & Perfection & \\
\hline 119 & 85 & 107 & 75 & 64 & \\
\hline$\bullet$ & $\bullet$ & $\bullet$ & $\bullet$ & $\bullet$ & 27 \\
\hline • & & & & & 17 \\
\hline - & & - & & & 16 \\
\hline • & • & - & & & 9 \\
\hline$\bullet$ & $\bullet$ & $\bullet$ & $\bullet$ & & 9 \\
\hline \multicolumn{5}{|c|}{ Other combinations } & 89 \\
\hline \multicolumn{5}{|c|}{ None of five principles } & 40 \\
\hline
\end{tabular}




\title{
Table 3: $\quad$ Comparison between types of waste for new product development and
}

\author{
manufacturing
}

\begin{tabular}{|c|c|c|}
\hline Type of waste & Manufacturing & New product development \\
\hline Waiting & $\begin{array}{ll}\text { - } & \text { Material and operation parts. } \\
\text { - } & \text { Maintenance. } \\
\text { - } & \text { Tools. } \\
\text { - } & \text { Operators. } \\
\text { Queue for further operations. }\end{array}$ & $\begin{array}{l}\text { Available human or machine capacity. } \\
\text { - Information waiting for people. } \\
\text { - Waiting for data, answers, requirements, } \\
\text { specifications, test results, approvals, } \\
\text { decisions, reviews, signatures. }\end{array}$ \\
\hline Transport & $\begin{array}{l}\text { - } \begin{array}{l}\text { Excessive movement of } \\
\text { pieces, materials, pieces and }\end{array} \\
\text { products. } \\
\text { - } \quad \text { Storage movement. } \\
\text { - } \quad \begin{array}{l}\text { Insertion or withdraw of } \\
\text { material/product/piece. }\end{array}\end{array}$ & $\begin{array}{l}\text { - } \\
\text { - } \quad \text { Back and forth of tasks or interrupted tasks. } \\
\text { - Inefficient communication. }\end{array}$ \\
\hline $\begin{array}{l}\text { Unnecessary } \\
\text { movement }\end{array}$ & $\begin{array}{l}\text { Operators' minimum } \\
\text { movements (reach, bend, } \\
\text { force). }\end{array}$ & $\begin{array}{ll}\text { - } & \text { Remote places. } \\
\text { - } & \text { Information search. } \\
\text { - } & \text { Direct access lack. }\end{array}$ \\
\hline $\begin{array}{l}\text { Inadequate } \\
\text { processes }\end{array}$ & $\begin{array}{l}\text { Over-dimensioning of process, } \\
\text { machines and equipment. } \\
\text { - Unnecessary accuracy of } \\
\text { product or process, not } \\
\text { meeting customer's real needs. }\end{array}$ & $\begin{array}{ll}\text { - } & \text { Unnecessary precision and details. } \\
\text { - } & \text { Unnecessary features and processes. } \\
\text { - } & \text { Inadequate competence use. } \\
\text { - } & \text { Inappropriate use of tools and methods. } \\
\text { - } & \text { Excessive accuracy. } \\
\text { - } & \text { Excessive transactions. } \\
\end{array}$ \\
\hline Inventory & $\begin{array}{ll}\text { Excessive raw-material } \\
\text { storage, semi-finished } \\
\text { products compared to } \\
\text { customer's demands. } \\
\text { - Waiting lines. } \\
\text { - } \quad \text { Storage among operations. }\end{array}$ & $\begin{array}{l}\text { - Unnecessary prototype and equipment tests. } \\
\text { - Waiting lines in critical path. }\end{array}$ \\
\hline Over production & $\begin{array}{l}\text { To produce more than } \\
\text { customer's order. } \\
\text { To produce before customer's } \\
\text { order. }\end{array}$ & $\begin{array}{l}\text { - } \quad \text { Low synchronism of solicited time and capacity. } \\
\text { - } \quad \text { Low synchronism of considered content. } \\
\text { - } \quad \text { Excessive information dissemination. } \\
\text { - Task redundancy. }\end{array}$ \\
\hline Defects & $\begin{array}{l}\text { - Components, materials, sub- } \\
\text { assembling or products that do } \\
\text { not have required quality. } \\
\text { - } \quad \text { Production internal defects. } \\
\text { - } \quad \text { Supplying defects. }\end{array}$ & $\begin{array}{l}\text { - Information with deficient quality. } \\
\text { - } \quad \text { Wrong database and information. } \\
\text { Poor tests and verifications. }\end{array}$ \\
\hline Reinvention & Not applicable. & $\begin{array}{ll} & \text { Project poor reuse. } \\
\text { - } & \text { Knowledge poor reuse. }\end{array}$ \\
\hline $\begin{array}{l}\text { Lack of } \\
\text { discipline }\end{array}$ & Not applicable. & $\begin{array}{l}\text { - } \\
\text { - } \quad \text { Badly defined roles, responsibilities and } \\
\text { rights. } \\
\text { - } \quad \text { Badly elaborated rules. } \\
\text { - } \quad \text { Insufficient predisposition to cooperate. } \\
\text { - } \\
\text { Incompetence or poor training. }\end{array}$ \\
\hline $\begin{array}{l}\text { IT resource } \\
\text { limitations }\end{array}$ & Not applicable. & $\begin{array}{ll} & \text { Poor compatibility. } \\
\text { - } & \text { Poor capacity. } \\
\text { - } & \text { Low capacity. } \\
\end{array}$ \\
\hline
\end{tabular}

Sources: Bauch (2004); Salgado et al. (2014). 
Table 4: $\quad$ Other principles of lean thinking for NPD.

\begin{tabular}{|c|c|}
\hline Principle & Sources \\
\hline Assessment tool & Sopelana et al. (2012). \\
\hline Chief engineer/leadership & $\begin{array}{l}\text { Baines et al. (2006), Ćatić and Vielhaber (2011), Dal Forno and Forcellini } \\
\text { (2013), Dem et al. (2012), Dombrowski and Zahn (2011), Khan et al. (2013), } \\
\text { Liker and Morgan (2006), Liker and Morgan (2011), Oppenheim (2004), } \\
\text { Powell et al. (2014), Ringen and Lodgaard (2009), Rossi et al. (2012), Sobek } \\
\text { II et al. (1998), Subramoniam et al. (2009), Swan and Furuhjelm (2010), von } \\
\text { Würtemberg et al. (2011) and Wang, Ming et al. (2011). }\end{array}$ \\
\hline Culture & $\begin{array}{l}\text { Baines et al. (2006), Liker and Morgan (2006), Ringen and Welo (2015), } \\
\text { Welo (2011), Welo and Ringen (2015), Welo et al. (2012) and Welo et al. } \\
\text { (2013). }\end{array}$ \\
\hline $\begin{array}{l}\text { Employees/People/ } \\
\text { Stakeholders }\end{array}$ & $\begin{array}{l}\text { Dombrowski and Zahn (2011), Powell et al. (2014), Qudrat-Ullah et al. (2012) } \\
\text { and Stenholm et al. (2015). }\end{array}$ \\
\hline Enablers & Tortorella et al. (2015). \\
\hline Flexibility & Morgan (2002), Powell et al. (2014) and Reinertsen and Shaeffer (2005). \\
\hline $\begin{array}{l}\text { Heavyweight project } \\
\text { manager/Strong project } \\
\text { manager/ Heavyweight } \\
\text { team structure }\end{array}$ & $\begin{array}{l}\text { Cusumano and Nobeoka (1998), Hille and Eseonu (2015), Hoppmann et al. } \\
\text { (2009), Hoppmann et al. (2011), Karlsson and Åhlström (1996) and Schuh et } \\
\text { al. (2008). }\end{array}$ \\
\hline Just in time & Becker and Wits (2015). \\
\hline $\begin{array}{l}\text { Kaizen/ Improvement } \\
\text { culture }\end{array}$ & $\begin{array}{l}\text { Gershenson and Pavnaskar (2003), Hille and Eseonu (2015) and Khan et al. } \\
\text { (2013). }\end{array}$ \\
\hline Late engineering changes & Ballé and Ballé (2005). \\
\hline Learning & Powell et al. (2014). \\
\hline Multi-project organisation & Cusumano and Nobeoka (1998). \\
\hline Respect for people & $\begin{array}{l}\text { Costa et al. (2014), da Costa et al. (2014), Dem et al. (2012), Oehmen and } \\
\text { Rebentisch (2010b), Oppenheim et al (2011) and Radeka and Sutton (2007). }\end{array}$ \\
\hline Standardisation & $\begin{array}{l}\text { Anand et al. (2009), Baines et al. (2007), Cusumano and Nobeoka (1998), Dal } \\
\text { Forno and Forcellini (2013), Dal Forno et al. (2011), Dal Forno et al. (2013a), } \\
\text { Dal Forno et al. (2013b), Dombrowski and Zahn (2011), Furuhjelm et al. } \\
\text { (2011), Gremyr and Fouquet (2012), Hille and Eseonu (2015), Hölttä et al. } \\
\text { (2010), Kamath and Liker (1994), Karademir and Cangelir (2013), Kirner et } \\
\text { al. (2013), Liker and Morgan (2006), Liker and Morgan (2011), Schuh et al. } \\
\text { (2008), Siyam et al. (2013), Sobek II et al. (1998), Swan and Furuhjelm } \\
\text { (2010), Wang, Quesada-Pineda et al. (2011), Welo and Ringen (2015), Welo } \\
\text { et al. (2012), Welo et al. (2013) and Yang and Cai (2009). }\end{array}$ \\
\hline Takt time & Oppenheim (2004). \\
\hline Transparency & Powell et al. (2014) and Ryan and Reik (2010). \\
\hline Variability & Reinertsen and Shaeffer (2005). \\
\hline $\begin{array}{l}\text { Visualisation*/visual } \\
\text { management/visual } \\
\text { planning }\end{array}$ & $\begin{array}{l}\text { Anand et al. (2009), Dal Forno and Forcellini (2013), Dal Forno et al. (2013a), } \\
\text { Dal Forno et al. (2013b), Dombrowski and Zahn (2011), Fouquet (2007), } \\
\text { Furuhjelm et al. (2011), Gingnell et al. (2012), Gremyr and Fouquet (2012), } \\
\text { Hille and Eseonu (2015), Liker and Morgan (2006), Liker and Morgan (2011), } \\
\text { Lindlöf and Söderberg (2011), Ringen and Lodgaard (2009), Saad et al. } \\
\text { (2013)*, Siyam et al. (2013), Ström et al. (2012), Subramoniam et al. (2009), } \\
\text { Swan and Furuhjelm (2010) and von Würtemberg et al. (2011). }\end{array}$ \\
\hline
\end{tabular}

* Visualisation by means of A3. 
Table 5: $\quad$ Extensions of lean product development.

\begin{tabular}{|c|c|}
\hline Conceptualisation & Sources \\
\hline Axiomatic design & Cabello et al. (2012). \\
\hline Balanced score card & Flores et al. (2010). \\
\hline Batch size reduction & Reinertsen (2005) and Reinertsen and Shaeffer (2005). \\
\hline Bottleneck (management) & $\begin{array}{l}\text { Beauregard, Bhuiyan and Thomson (2008), Beauregard, Thomson } \\
\text { and Bhuiyan (2008) and Wang et al (2011). }\end{array}$ \\
\hline Breakdown of customer value & Browning (2003)*, Khan (2012). \\
\hline Cadence & Reinertsen (2005). \\
\hline Cause and effect & El-Sayed (2012). \\
\hline $\begin{array}{l}\text { Communication/visual } \\
\text { communication }\end{array}$ & Fouquet (2007), Kirner et al. (2013) and Liker and Morgan (2006). \\
\hline $\begin{array}{l}\text { Cross-functional team/compact } \\
\text { team/ team commitment }\end{array}$ & $\begin{array}{l}\text { Fouquet (2007), Karlsson and Ahlström (1996), Karademir and } \\
\text { Cangelir (2013), Kerga et al. (2015), Liker and Morgan (2006), } \\
\text { McNeel and Lawrence (2004), Morgan (2002), Ringen and Holtskog } \\
\text { (2013) and Sobek II et al. (1998). }\end{array}$ \\
\hline Design for Six Sigma (DFSS) & $\begin{array}{l}\text { Bertelli and Loureiro (2015), El-Sayed (2012) and Lee and Chang } \\
\text { (2010). }\end{array}$ \\
\hline Design for $\mathrm{X}$ & $\begin{array}{l}\text { Dombrowski and Schmidt (2013), Dombrowski et al. (2014) and } \\
\text { Haque and James-Moore (2004a). }\end{array}$ \\
\hline Design of experiments & Cabello et al. (2012) and Tähemaa et al. (2012). \\
\hline Design task heijunka/levelling & Gershenson and Pavnaskar (2003) and Swan and Furuhjelm (2010). \\
\hline DFM and DFA, DFMA & Bertelli and Loureiro (2015), Furian et al. (2013), Khan (2012). \\
\hline $\begin{array}{l}\text { DFQC/target costing/quality and } \\
\text { cost production }\end{array}$ & $\begin{array}{l}\text { Ballé and Ballé (2005), Negroni and Trabasso (2009), Tähemaa et al. } \\
\text { (2012) and Wasim et al. (2013). }\end{array}$ \\
\hline DFV & Cabello et al. (2012). \\
\hline $\begin{array}{l}\text { Early supplier involvement/supplier } \\
\text { involvement }\end{array}$ & $\begin{array}{l}\text { Dal Forno and Forcellini (2013), Dal Forno et al. (2011), Dal Forno, } \\
\text { Forcellini and Bornia (2013), Dal Forno, Forcellini, de Miranda and } \\
\text { Bornia (2013), Gurumurthy and Kodali (2012), Kamath and Liker } \\
\text { (1994), Karlsson and Åhlström (1996), Kirner et al. (2013), Liker and } \\
\text { Morgan (2006), Radeka and Sutton (2007) and Saunders et al. (2014). }\end{array}$ \\
\hline Families of parts & Anand and Kodali (2008). \\
\hline Feedback loops & Reinertsen and Shaeffer (2005). \\
\hline Flexibility & Morgan (2002) and Reinertsen and Shaeffer (2005). \\
\hline FMEA & Bertelli and Loureiro (2015) and Endris et al. (2012). \\
\hline Frontloading & $\begin{array}{l}\text { Dombrowski and Zahn (2011), Gingnell et al. (2012), Liker and } \\
\text { Morgan (2006), Mahlamäki et al. (2009) and Radeka and Sutton } \\
\text { (2007). }\end{array}$ \\
\hline GOLCAD & Gershenson and Pavnaskar (2003). \\
\hline Human factoring engineering & Institoris and Bligard (2014). \\
\hline Innovative environment & Wohnhas (2014). \\
\hline Integrated computer-based solutions & Karademir and Cangelir (2013). \\
\hline Integrated product team & Rebentisch (2005). \\
\hline $\begin{array}{l}\text { Integration of customers/customers } \\
\text { requirement }\end{array}$ & $\begin{array}{l}\text { Ballé and Ballé (2005), Kirner et al. (2013), Liker and Morgan (2006) } \\
\text { and Ringen and Holtskog (2013). }\end{array}$ \\
\hline Kano model & El-Sayed (2012). \\
\hline $\begin{array}{l}\text { Knowledge-based engineering, } \\
\text { systems/ re-use of knowledge/ Re- } \\
\text { use of designs/ knowledge } \\
\text { management/ knowledge creation }\end{array}$ & $\begin{array}{l}\text { Amin et al. (2010), Flores et al. (2010), Anand and Kodali (2008), } \\
\text { Ćatić and Sobek II (2013), Ćatić and Vielhaber (2011), Dal Forno et } \\
\text { al. (2011), Dal Forno, Forcellini and Bornia (2013), Gautam et al. } \\
\text { (2007), Harris et al. (2006), Helander et al. (2015), Khan (2012), } \\
\text { Khan et al. (2013), Léon and Farris (2011), Lindlöf et al. (2013), } \\
\text { Maksimovic (2013), Radeka and Sutton (2007), Ringen and Welo } \\
\text { (2015), Rossi et al. (2012), Sorli et al. (2010), Stenholm et al. (2015), } \\
\text { Swan and Furuhjelm (2010), von Würtemberg et al. (2011), Wasim et } \\
\text { al. (2013), Welo (2011), Welo and Ringen (2015), Welo et al. (2012), } \\
\text { Welo et al. (2013), Wohnhas (2014) and Yang and Cai (2009). }\end{array}$ \\
\hline Lean knowledge life cycle & Furian et al. (2013). \\
\hline
\end{tabular}




\begin{tabular}{|c|c|}
\hline $\begin{array}{l}\text { Learning networks/Organisational } \\
\text { learning }\end{array}$ & Dal Forno and Forcellini (2013) and Liker and Morgan (2006). \\
\hline Life-cycle management & $\begin{array}{l}\text { Dem et al. (2012), Dombrowski and Schmidt (2013), Dombrowski et } \\
\text { al. (2014), Hines et al. (2006), Murman (2008), Sorli et al.(2012), } \\
\text { Vosgien et al. (2011) and Walton (1999). }\end{array}$ \\
\hline Management & Oppenheim (2004). \\
\hline Machigaiyoke & Gershenson and Pavnaskar (2003). \\
\hline $\begin{array}{l}\text { Modularisation/modular } \\
\text { design/modularity }\end{array}$ & $\begin{array}{l}\text { Anand and Kodali (2008), Anand et al. (2009), Cusumano and } \\
\text { Nobeoka (1998), Dal Forno and Forcellini (2013), Dal Forno, } \\
\text { Forcellini, de Miranda and Bornia (2013), El-Sayed and El-Sayed } \\
\text { (2012), Gautam et al. (2007), Powell et al. (2014), Rossi et al. (2012) } \\
\text { and Walton (1999). }\end{array}$ \\
\hline MOGA & Cabello et al. (2012). \\
\hline Obeya & Rossi et al. (2012). \\
\hline Performance & Ringen and Welo (2015). \\
\hline $\begin{array}{l}\text { Platform architecture/platform of } \\
\text { products }\end{array}$ & Bjarnoe (2006), Harland and Uddin (2014) and Rebentisch (2005). \\
\hline Poka-yoke & Wasim et al. (2013). \\
\hline Process architecture & Flores et al. (2011) and Flores et al. (2012). \\
\hline Project portfolio management & Dombrowski and Zahn (2011) and Letens et al. (2011). \\
\hline QFD/House of quality & $\begin{array}{l}\text { Bertelli and Loureiro (2015), Choothian (2014), El-Sayed (2012), } \\
\text { Endris et al. (2012), Haque and James-Moore (2004a) and Tähemaa } \\
\text { et al. (2012). }\end{array}$ \\
\hline Quality management methods & Lee and Chang (2010). \\
\hline Queue management & Choothian (2014). \\
\hline Rapid local adjustments & Reinertsen (2005). \\
\hline RDM & Cabello et al. (2012). \\
\hline Resources efficiency & Wohnhas (2014). \\
\hline Reward and motivation process & Haque and James-Moore (2004a). \\
\hline Risk management & Murman (2008) and Oehmen and Rebentisch (2010a). \\
\hline Robust Engineering & Bertelli and Loureiro (2015). \\
\hline Role of prototype & Kamath and Liker (1994). \\
\hline SE & $\begin{array}{l}\text { Dal Forno and Forcellini (2013), Khan et al. (2013), Karlsson and } \\
\text { Ahlström (1996) and Kirner et al. (2013). }\end{array}$ \\
\hline Single minute exchange of projects & Gershenson and Pavnaskar (2003). \\
\hline Smart assemblies & Cabello et al. (2012). \\
\hline Stabilisation & $\begin{array}{l}\text { Liker and Morgan (2006), Ringen and Welo (2015), Welo and } \\
\text { Ringen (2015), Welo et al. (2012) and Welo et al. (2013). }\end{array}$ \\
\hline Stand-up meeting & Choothian (2014). \\
\hline Strategy & Khan (2012) and Welo (2011). \\
\hline Structural organisation & Dal Forno and Forcellini (2013). \\
\hline System perspective & Welo (2011). \\
\hline Taguchi method & Cabello et al. (2012). \\
\hline Technology/tools & Powell et al. (2014), Qudrat-Ullah et al. (2012). \\
\hline TRIZ & Bertelli and Loureiro (2015). \\
\hline Up-to-date data & Karademir and Cangelir (2013). \\
\hline Virtual simulation & $\begin{array}{l}\text { Dal Forno and Forcellini (2013) and Dal Forno, Forcellini, de } \\
\text { Miranda and Bornia (2013). }\end{array}$ \\
\hline VRM & Cabello et al. (2012). \\
\hline Workflow management & $\begin{array}{l}\text { Baines et al. (2007), Ballé and Ballé (2005) and Liker and Morgan } \\
\text { (2006). }\end{array}$ \\
\hline
\end{tabular}


Table 6: $\quad$ Other methods for new product development.

\begin{tabular}{|c|c|}
\hline Conceptual model & Sources \\
\hline $\begin{array}{l}\text { Advanced Product Development (Anderson, } \\
\text { 1997). }\end{array}$ & Walton (1999, p. 12). \\
\hline Axiomatic design (Suh, 1990). & Pavnaskar and Gershenson (2005, p. 441). \\
\hline Design concepts (Evans, 1959). & Singer et al. (2009, p. 3). \\
\hline $\begin{array}{l}\text { Innovation funnel (Wheelwright and Clark, } \\
\text { 1992). }\end{array}$ & $\begin{array}{l}\text { Morgan (2002), Singer et al. (2009, p. 5) andWalton (1999, pp. } \\
\text { 12-13). }\end{array}$ \\
\hline Major developmental stages (Clark and & Morgan (2002), Saunders et al. (2014, pp. 310, 322) and \\
\hline Fujimoto, 1991). & Walton (1999, pp. 14-15). \\
\hline Mechanical design process (Ullman, 2009) & Ćatić and Vielhaber (2011, p. 160). \\
\hline P-51 Mustang development. & Bjarnoe (2006). \\
\hline $\begin{array}{l}\text { Process model for product development } \\
\text { (Rauhut, 2011) }\end{array}$ & Schuh et al. (2014, pp. 394-395) \\
\hline Pugh matrix, Pugh (1991). & $\begin{array}{l}\text { Al-Ashaab, Golob et al. (2013, pp. 8, 12-14), Singer et al. } \\
(2009, \text { p. 5) and Ward et al. (1995, p. 48). }\end{array}$ \\
\hline $\begin{array}{l}\text { Shigley's model for design processes (Shigley } \\
\text { and Mischke, 1989). }\end{array}$ & Ward et al. (1995). \\
\hline $\begin{array}{l}\text { Stage-gate model for innovation (Rozenfeld et } \\
\text { al., 2006). }\end{array}$ & Wang, Ming et al. (2011). \\
\hline $\begin{array}{l}\text { Stage-gate process (Cooper et al., 2001, p. } \\
272 \text { ). }\end{array}$ & Beauregard et al. (2011) and Salgado et al. (2015, p. 31). \\
\hline $\begin{array}{l}\text { Systematic development of products (Baxter, } \\
\text { 1995). }\end{array}$ & El-Sayed (2010, p. 195) and El-Sayed and El-Sayed (2012). \\
\hline $\begin{array}{l}\text { Systematic engineering design and practice } \\
\text { (Pahl and Beitz, 2007). }\end{array}$ & $\begin{array}{l}\text { Dombrowski and Schmidt (2013) and Schuh et al. (2014, pp. } \\
\text { 394-395). }\end{array}$ \\
\hline $\begin{array}{l}\text { Ulrich and Eppinger's }(1995,2000,2004, \\
\text { 2007, 2008) product design and development } \\
\text { process. }\end{array}$ & $\begin{array}{l}\text { Ćatić and Vielhaber (2011, p. 160), Chase (2000, pp. 4-5), } \\
\text { Cusumano and Nobeoka (1998), El-Sayed (2010, p. 195; 2012, } \\
\text { pp. 2-3), Mayrl et al. (2013, p. 494), Walton (1999, pp. 13-14) } \\
\text { and Wang, Ming et al. (2011, p. 7). }\end{array}$ \\
\hline VDI guidelines. & $\begin{array}{l}\text { Ćatić and Vielhaber (2011, p. 160) and Schuh et al. (2014, pp. } \\
\text { 394-395). }\end{array}$ \\
\hline $\begin{array}{l}\text { Waterfall model (Petersen et al., 2009; Royce, } \\
\text { 1970). }\end{array}$ & Salgado et al. (2015, p. 31). \\
\hline Wu's (1994) product development process. & El-Sayed (2010, p. 195). \\
\hline
\end{tabular}




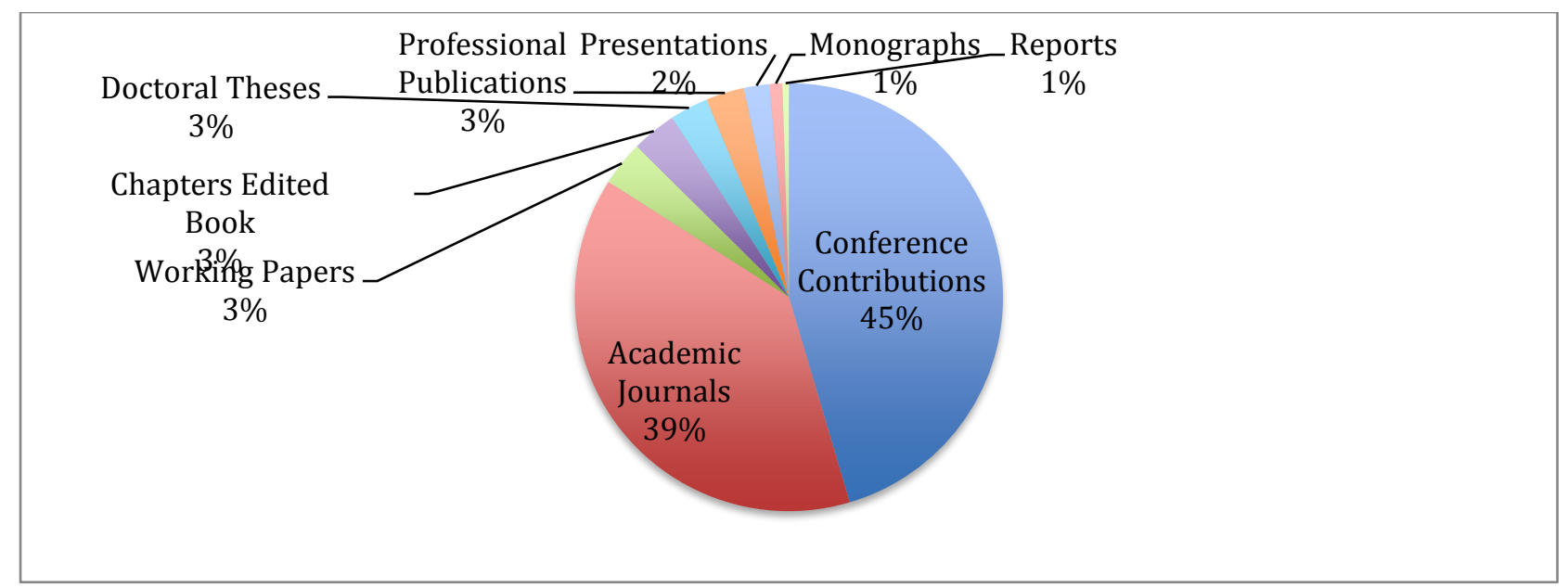

Figure 1: Overview of types of retrieved publications. 


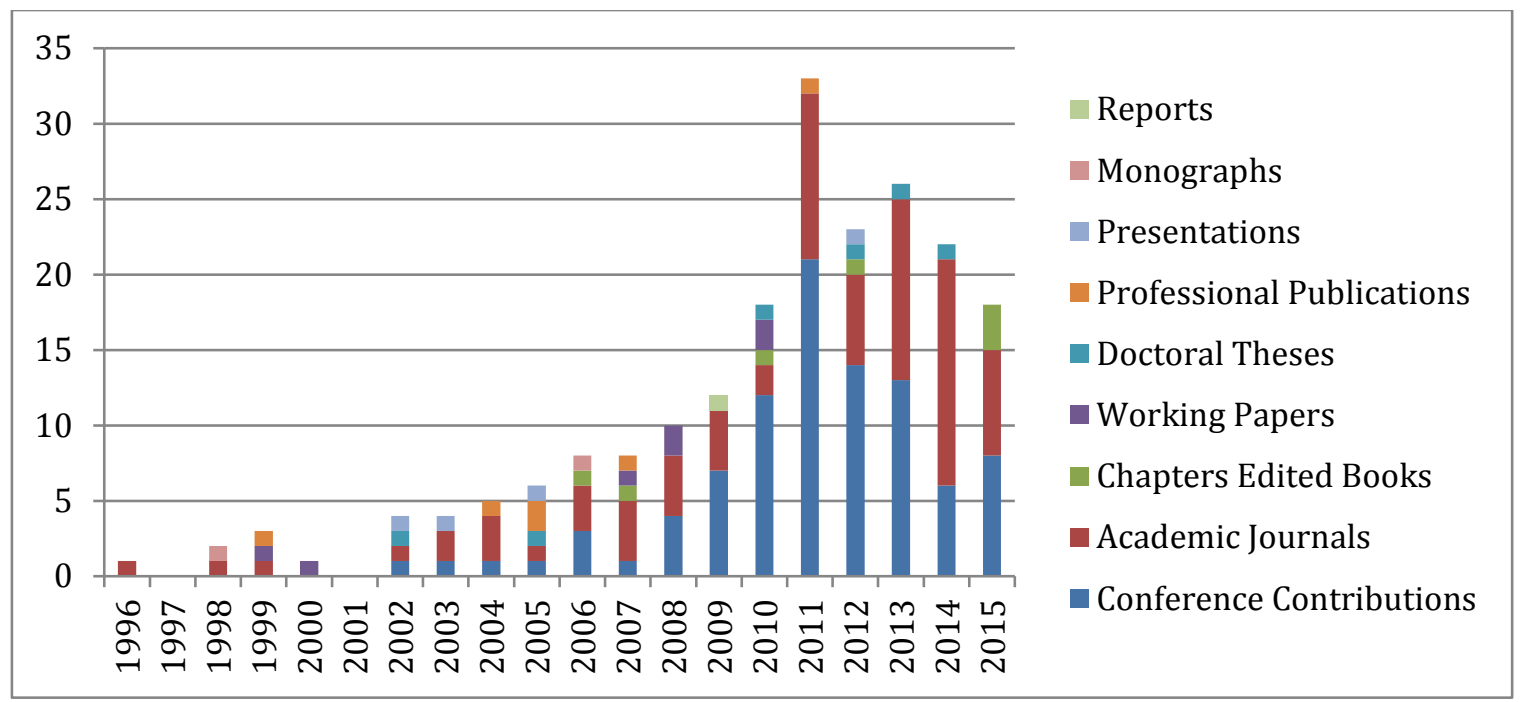

Figure 2: Overview of types of publications by year. 


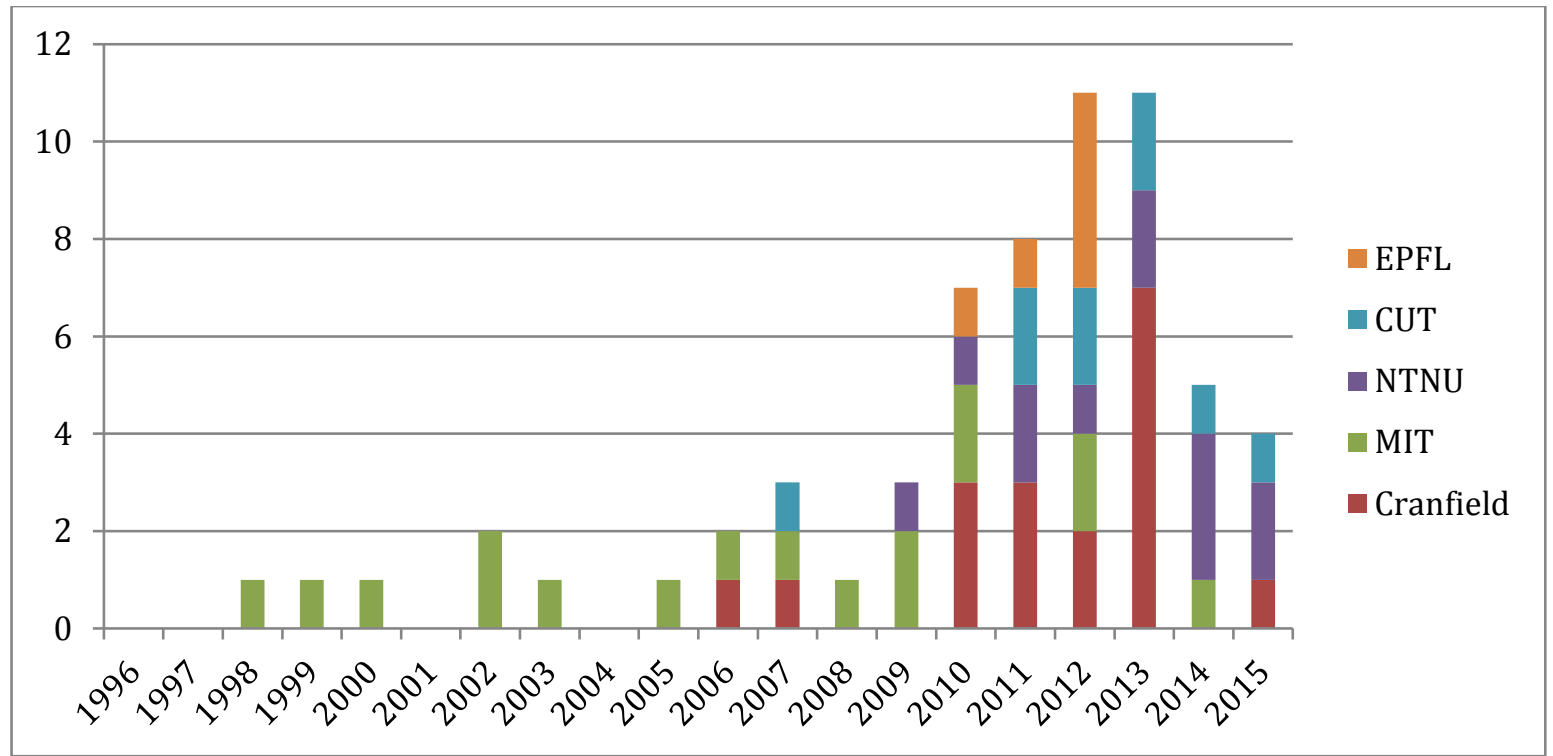

Figure 3: Annual publications per leading institute. 


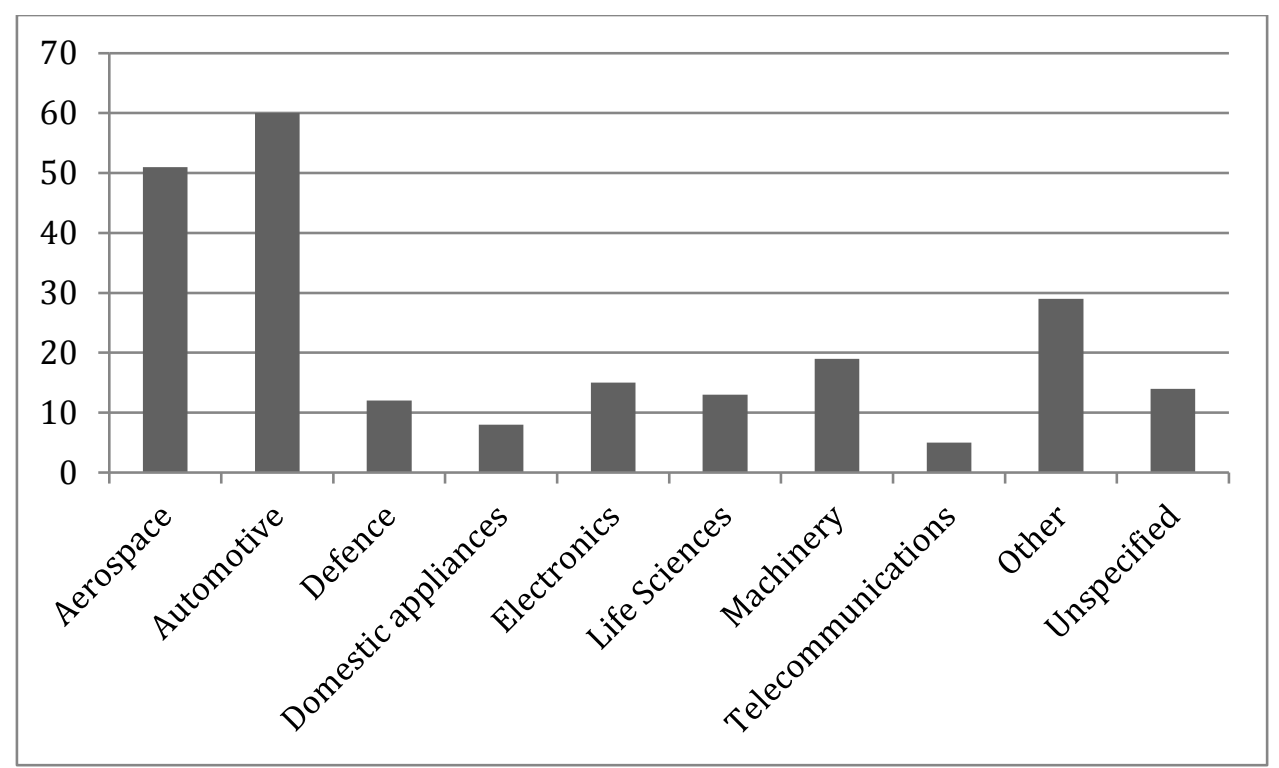

Figure 4: Frequency of industries across publications (excluding propositional papers not directed at a specific industry). 


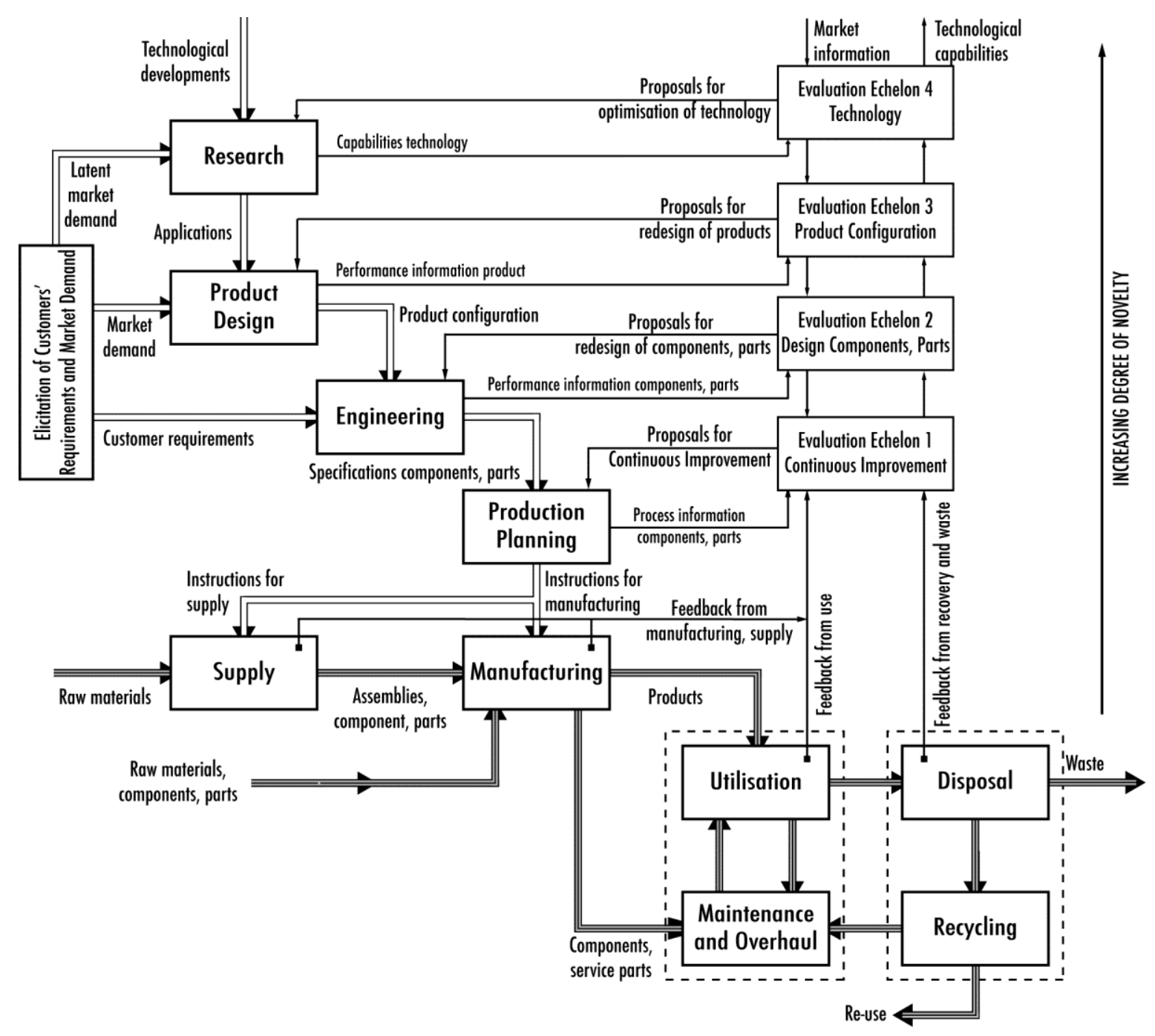

Figure 5: Generic reference model for engineering, manufacturing and deployment processes (Dekkers et al., 2013, p. 321). 


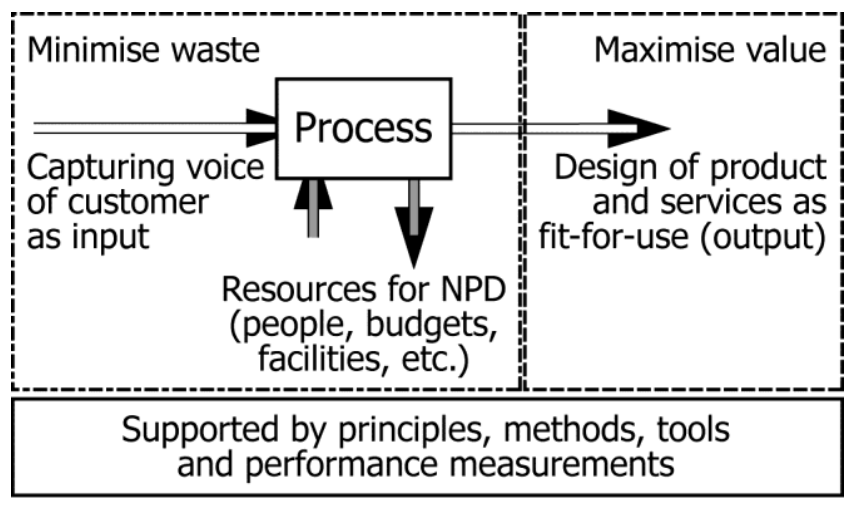

Figure 6: Waste and value in NPD (adapted from Hoppmann [2009, p. 15] by using process modelling from Dekkers [2015, pp. 78- 79]). 

Management and leadership
- Chief engineer
- Heavyweight team structure
- Project portfolio management
- ...
Cross-functional integration
- Concurrent engineering
- Early supplier involvement
- Visual managemen

Value for customer

- Customer involvement

- Value engineering

- Axiomatic design

- TRIZ

-...

Methods for design and engineering

- Point-based concurrent engineering

- Pugh's controlled convergence method

- Stage-gate processes

- Standardisation/modular design

- Systems engineering$$
\text { -... }
$$

Tools for design and

engineering

- Design for six sigma, etc.

- Design of experiments/prototyping

- FMEA

- QFD

- ...
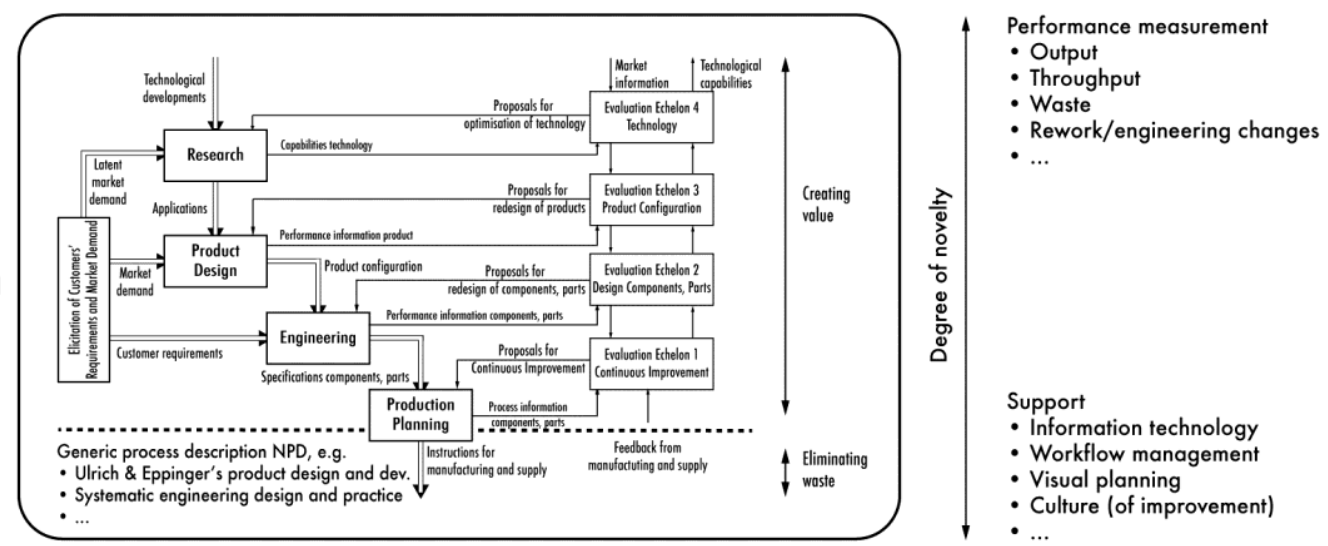

Figure 7: Overview of approaches, methods and tools for new product development. 